\title{
Escherichia coli in extra-intestinal infections
}

\author{
BY IDA ØRSKOV AND FRITS ØRSKOV \\ International Escherichia and Klebsiella Centre (WHO), Statens Seruminstitut, \\ Copenhagen, Denmark
}

\section{INTRODUCTION}

When Theodor Escherich $(1885 a, b)$ first described Escherichia coli he looked on it as a saprophytic organism. Soon several investigators found that colibacteria could be isolated from intestinal infections and from many infections outside the intestine, like urinary tract infections (UTI), cholecystitis, wound infections, meningitis, septicaemia, pulmonary infections, and many more. Uhlenhuth (1897) showed that coli strains from pathological processes were more pathogenic in animal experiments than strains isolated from the normal intestine. Smith (1927), who examined strains from white scours in calves, showed that spontaneous acapsular mutants could be obtained from certain colibacteria, and that such mutants were less virulent when injected intra-peritoneally into guinea-pigs.

Several attempts to define toxins in coli strains were also carried out. Interest was centred on skin necrotizing toxins and on haemolysins. Most investigators agreed that it was not possible to isolate the toxins and that the haemolytic and skin-necrotizing abilities were only found in close association with actively dividing bacteria.

Several investigators in the first three decades of this century tried to classify $E$. coli, hoping to be able to define certain strains or serotypes as virulent. However, these attempts did not lead to any conclusive results.

In the 1940s Kauffmann $(1943,1944 a, b, 1947)$ applied to $E$. coli the serological techniques that he and other investigators had developed for typing of salmonella strains. He showed that coli strains had $\mathrm{O}$ antigens that in their serological qualities were very similar to those found in salmonella and, more importantly, that many strains isolated from pathological processes outside the intestinal tract had surface antigens that would inhibit agglutination of the live culture in a so-called $\mathrm{O}$ antiserum, i.e. an antiserum produced by immunization of rabbits with boiled culture. He called such antigens L antigens (Kauffmann, 1943). He was now able to establish the first $E$. coli typing scheme (Kauffmann, 1944a). Knipschildt (1945) and Vahlne (1945), both close pupils of Kauffmann, developed and refined the typing principles by extension of the number of $O$ groups and by describing two new varieties of surface antigens called $A$ and $B$ antigens, both of which could inhibit $O$ agglutination (Knipschildt, 1945). At that time the chemical nature of the $\mathrm{L}, \mathrm{A}$ and $\mathrm{B}$ antigens was not known; however, it was decided to name them collectively as $\mathrm{K}$ antigens (Kauffmann \& Vahlne, 1945). For more details about the history, serology and immunochemical nature of $E$. coli K antigens see Ørskov et al. (1977) and Jann \& Jann (1983). 
Kauffmann and his early group of collaborators were, however, also highly interested in the pathogenic properties of $E$. coli in extra-intestinal diseases, and in 1947 he could sum up his own results together with those of Knipschildt (1945), Ewertsen (1946), Vahlne (1945) and Sjöstedt (1946) in this way: 'The results show consistently that certain serological types belonging to the frequent $\mathrm{O}$ groups possess a particular pathogenicity for man and animals. This applies especially to $O$ groups 1, 2, 4, 6, 8 and 9. Haemolytic and necrotizing strains are of frequent occurrence with $O$ groups 2,4 and 6 , on which account especially group 6 comprises highly toxic strains. The toxicity of the strains depends on the type $(\operatorname{read} \mathrm{O}: \mathrm{K}: \mathrm{H}$ type) of the strain and it is a constant character' (Kauffmann, 1947). When Kauffmann and his collaborators described the traits that might differentiate pathogenic $E$. coli from non-pathogenic ones they compared two groups of strains, one which comprised strains from all types of extra-intestinal infections and one which came from the faeces of healthy individuals. It should be remembered that at that time the association between certain strains and intestinal disease (EPEC, ETEC and EIEC) had not yet been described. Investigations in the years since these early examinations have, however, shown that three groups of extra-intestinal coli infections (UTI, neonatal meningitis and non-neonatal septicaemia) need to be treated separately even though several traits and virulence factors may be found in strains isolated from all extra-intestinal diseases.

In dealing with the activities of $E$. coli outside the intestinal tract we have in this review paper, quite appropriately for a bacterial baptismal centenary, paid most attention to the bacterium Escherichia coli, and only in a few places have we given details from the many investigations that describe the response of the host.

\section{URINARY TRACT INFECTIONS (UTI)}

$E$. coli is the most common urinary pathogen found in non-hospitalized patients of all ages. In general UTI is diagnosed by demonstration of $\geqq 10^{5}$ bacteria per $\mathrm{ml}$ of midstream urine or by any number of bacteria from urine obtained by suprapubic bladder puncture. Recently it has been proposed to use a lower limit than $10^{5}$ bacteria per $\mathrm{ml}$ for the demonstration of UTI (Stamm et al. 1982). Some cases of bacteriuria are asymptomatic (ABU), some are limited to the bladder or lower urinary tract (cystitis), and some involve the upper tract, i.e. the pelvis and the kidneys (pyelonephritis).

Recurrent UTI is not uncommon; it can be caused by the $E$. coli strain that caused the first attack but which was only temporarily suppressed (relapse) or by an unrelated strain (reinfection). Abnormalities of the urine flow caused by malformations, stones, residual urine and vesico-ureteric reflux predispose for recurrent UTI, but such abnormalities cannot always be demonstrated in recurrent UTI.

Several reports on $E$. coli from UTI do not distinguish between these different infections. This is stressed because the coli strains isolated from each of these types of UTI show certain characters or virulence factors with varying prevalence.

It is generally accepted that UTIs are usually ascending infections caused by bacteria originating in the intestinal tract, because a high similarity exists between 
E. coli strains from urine and faeces of infected individuals (Turck, Petersdorf \& Furnier, 1962; Vosti et al. 1964; Grüneberg, 1969). The infecting E. coli type can often be isolated from the faeces before or at onset of symptomatic UTI (Grüneberg, Leigh \& Brumfitt, 1968; Lidin-Janson et al. 1977), and it has furthermore been shown that colonization of the vaginal introitus and the periurethral area precedes the infection (Cooke \& Ewins, 1975; Bollgren \& Winberg, 1976; Fowler \& Stamey, 1977).

Two theories have been presented to explain the emergence of UTI with a faecal strain: (1) the prevalence theory which says that the urinary strain has dominated the faecal flora, and (2) the special pathogenicity theory which proposes that certain virulence factors have to be present in strains able to invade the urinary tract (Grüneberg, Leigh \& Brumfitt, 1968). The two theories are probably not contradictory, but the correctness of the prevalence theory is difficult to prove because of the lack of prospective studies. However, from studies carried out in recent years it has appeared that $E$. coli isolated from non-obstructive cases of acute pyelonephritis without reflux are characteristically endowed with certain traits considered of importance for virulence. The traits are: certain $\mathrm{O}$ groups; certain $\mathrm{K}$ antigens; amount of $\mathrm{K}$ antigen ; certain adhesins; haemolysin production; resistance to serum bacteridical activity; resistance to phagocytosis; siderophore production.

\section{$O$ antigens}

E. coli strains of a relative small number of $\mathrm{O}$ groups, namely $\mathrm{O} 1, \mathrm{O} 2, \mathrm{O4}, \mathrm{O6}$, $\mathrm{O} 7, \mathrm{O} 18$ and $\mathrm{O} 75$, have been reported to account for a major part of $\mathrm{O}$-groupable UTI strains from different parts of the world (Ranz, 1962; Turck, Petersdorf \& Furnier, 1962; Kunin, Deutscher \& Paquin, 1964; Vosti et al. 1964; McGeachie, 1965 ; Ørskov \& Ørskov, 1967; Grüneberg, Leigh \& Brumfitt, 1968). It has also been demonstrated that strains from the first infection showed a greater concentration of these $\mathrm{O}$ groups compared with strains from recurrent infections (McGeachie, 1965: Bergström et al. 1967; Ørskov \& Ørskov, 1967; Mabeck, Ørskov \& Ørskov, $1971 b$; Sietzen, 1979). When UTIs were diagnosed as ABU, cystitis or pyelonephritis, it was furthermore demonstrated that strains of the above-mentioned $\mathrm{O}$ groups with the addition of $\mathrm{O} 16$ were found in $\sim 80 \%$ of pyelonephritis, in $\sim 59 \%$ of cystitis and in $31 \%$ of ABU strains (Lindberg et al. 1975a). In addition, strains from pyelonephritis without reflux more frequently belong to these $\mathrm{O}$ groups than do strains from pyelonephritis with reflux (Lomberg et al. 1984; Svanborg Edén et al. 1985). No particular toxicity of these $O$ antigens compared with other $O$ antigens, i.e. these lipopolysaccharides as such, has ever been shown; but it has been shown by comparing isogenic $075^{+} \mathrm{K} 5$ and $\mathrm{O75}^{-} \mathrm{K} 5$ isolates that presence of $\mathrm{O}$ antigen contributes to the ability to persist in the mouse kidneys and bladders (Hagberg et al. 1984).

It has been reported that spontaneously agglutinating strains (rough) were particularly frequent among ABU strains (Olling et al. 1973; Lindberg et al. 1975a), and that $\mathrm{O}$ antigens of strains from acute pyelonephritis and $\mathrm{ABU}$ belonging to the same $O$ groups behaved differently, e.g. strains from acute pyelonephritis absorbed $\mathrm{O}$ antibodies in rabbit $\mathrm{O}$ antisera better than did strains from cases of $\mathrm{ABU}$ (Lindberg et al. 1975b). A change from $\mathrm{O}$ group typability to spontaneous 
agglutination in successive UTI isolates has also been observed (Bettelheim \& Taylor, 1969; Lindberg et al. 1975b; Webb, Goodwin \& Green, 1982). These findings have been explained by a loss of full-length $O$ polysaccharide chains of the lipopolysaccharides in patchwise areas of the bacterial surface (Webb, Goodwin \& Green, 1982). As pointed out by Hanson et al. (1977), such changes may be an example of 'antigenic drift' induced by antibodies of the host as noted for Vibrio cholerae in mice (Sack \& Miller, 1969).

\section{$K$ antigens}

Vahlne (1945) and Sjöstedt (1946) showed that presence of $K$ antigen was more common in UTI strains than in faecal strains. The most frequently found types are K 1, K2, K 3, K5, K 12 and K 13 (Mabeck, Ørskov \& Ørskov, 1971 $a$; Kaijser et al. 1977; Ørskov et al. 1982a). Glynn \& Howard (1970) and McCabe et al. (1975) demonstrated that the $K$ antigen was present in larger quantities in urinary strains than in strains from faeces; strains from the upper urinary tract were particularly rich in $\mathrm{K}$ antigen (Glynn, Brumfitt \& Howard, 1971; Brooks et al. 1980). The $\mathrm{K}$ antigens were not serologically typed. The amount of $K$ antigen was measured by the ability of culture supernatant to inhibit the agglutination of sheep red blood cells by antiserum. Kaijser (1973) measured the amount of K antigens K1, K2 and $\mathrm{K} 13$, both by the haemagglutination-inhibition technique and by crossed immunoelectrophoresis, and provided additional support for the finding that $\mathrm{K}$ antigen is present significantly more often and in greater amounts among $E$. coli from cases of pyelonephritis than among strains from cystitis or from stools of healthy children. In this case both $O$ and $K$ antigens were determined, and pyelonephritis and cystitis strains of the same $O: K$ type differed in $K$ antigen amount. Strains rich in $\mathbf{K}$ antigen were less sensitive than others to phagocytosis as well as to bactericidal killing (Glynn \& Howard, 1970).

Kétyi, Naumann \& Nimmich (1983) inoculated several rough $E$. coli strains with or without the $\mathrm{K} 1$ antigen directly into the bladder (i.e. through the abdominal wall) of suckling mice (Kétyi, 1981). The strains were not isogenic. After 14-24 days the bladder and kidney infections were estimated. Possession of the K1 antigen was shown to have a virulence-enhancing effect. By comparing different $\mathrm{K}^{+}$strains with their $\mathrm{K}^{-}$mutants Verweig-van Vught et al. (1983) found that $\mathrm{K}$ antigens were of minor importance for mouse nephropathogenicity. They only examined one $\mathrm{K}^{+}$strain, and this was not nephropathogenic but was able to cause a more general infection (termed group III strains), and this ability was lost by the $\mathrm{K}^{-}$mutant. However, in the model used by Verweig-van Vught et al. (1983) the bacteria were injected intravenously, and viable counts of the kidneys were performed $8 \mathrm{~h}$ after injection (van den Bosch, de Graaf \& MacLaren, 1979). In contrast to this model, that of Kétyi (1981) was designed to bring about an ascending UTI.

\section{$O: K: H$ serotypes}

Mabeck, Ørskov \& Ørskov (1971 $a$ ) found that symptoms of acute pyelonephritis were not correlated with particular $\mathrm{H}$ antigens, but that some $E$. coli serotypes, namely $\mathrm{O} 2: \mathrm{K} 1: \mathrm{H} 4, \mathrm{O} 4: \mathrm{K} 12: \mathrm{H} 5$ and $\mathrm{O6}: \mathrm{K} 2 \mathrm{ac}: \mathrm{H} 1$, were associated with a disproportionately high frequency of acute pyelonephritis. Ørskov et al. (1982b) 
reported that strains of serotypes $\mathrm{O} 1: \mathrm{K} 1: \mathrm{H} 7, \mathrm{O} 4: \mathrm{K} 12: \mathrm{H} 5, \mathrm{O} 6: \mathrm{K} 2: \mathrm{H} 1$ and $\mathrm{O} 16: \mathrm{K} 1: \mathrm{H} 6$ were more frequently associated with pyelonephritis than with cystitis, while the opposite was true for strains of serotype $06: \mathrm{K} 13: \mathrm{H} 1$, which was therefore considered as a cystitic type. Väisänen-Rhen et al. (1984) found that $57 \%$ of $\mathrm{O}$ antigen-typable strains from pyelonephritis belonged to the following six serotypes: $\mathrm{O} 1: \mathrm{K} 1: \mathrm{H} 7, \mathrm{O} 4: \mathrm{K} 12: \mathrm{H} 1, \mathrm{O} 4: \mathrm{K} 12: \mathrm{H} 1, \mathrm{O} 6: \mathrm{K} 2: \mathrm{H} 1$, $\mathrm{O} 16: \mathrm{K} 1: \mathrm{H} 6$ and $\mathrm{O} 18 \mathrm{ac}: \mathrm{K} 5: \mathrm{H} 7$; the serotype $\mathrm{O6}: \mathrm{K} 13: \mathrm{H} 1$ was also here associated with cystitis.

\section{Haemolysin}

In 1921 Dudgeon, Wordley \& Bawtree pointed out that haemolytic strains are more common among UTI strains than among strains from the faecal flora. This fact was later confirmed by several authors, e.g. Cooke \& Ewins (1975), Minshew et al. (1978) and Hacker et al. (1983). In addition, the percentage of haemolytic strains has been found to be higher among strains from pyelonephritis than among those from cystitis, $\mathrm{ABU}$ or the intestinal tract (Väisänen-Rhen et al. 1984). Knipschildt (1945) and Kauffmann (1947) demonstrated that haemolytic E. coli mainly belonged to strains of $O$ groups 2,4 and 6 , and UTI strains are frequently of these $\mathrm{O}$ groups or of $\mathrm{O}$ groups 18 and 75, which are also often haemolytic (Cooke \& Ewins, 1975; Hughes, Phillips \& Roberts, 1982). However, strains of some $\mathrm{O}: \mathrm{K}: \mathrm{H}$ serotypes within these $\mathrm{O}$ groups are more often haemolytic than others (Vahlne, 1945; Sjöstedt, 1946). Van den Bosch et al. (1981) studied the influence on virulence of haemolysin production in the experimental mouse model mentioned above, which involves intravenous injection of the bacteria (van den Bosch, de Graaf \& MacLaren, 1979). They concluded that haemolysin production was a decisive virulence factor in most of the mouse nephropathogenic strains, called group II strains, since 6 out of 7 strains became avirulent after elimination of the ability to produce haemolysin. These 6 strains were of $\mathrm{O}: \mathrm{K}$ serotypes $\mathrm{O} 6: \mathrm{K} 2$, 075: $\mathrm{K}^{-}, \mathrm{O} 4: \mathrm{K} 3$ or $\mathrm{O} 139: \mathrm{K} 82$. Transfer of an $\mathrm{Hly}$ plasmid to a $\mathrm{K} 12$ strain did not render this strain virulent in the same mouse model (Waalwijk et al. 1982). Reduction or elimination of the haemolysin production in a group II strain by insertion of transposon Tn5 in the hly gene resulted in reduction or loss of nephropathogenicity (Waalwijk \& de Graaf, 1983). In the suckling mouse model (Kétyi, 1981), where bacteria are introduced via the bladder, Kétyi, Naumann \& Nimmich (1983) found that rough strains with haemolytic activity induced bladder and kidney infections, while rough strains without this activity were non-virulent. Van den Bosch, Emödy \& Kéty (1982) compared this model with that involving intravenous ingestion of bacteria and found that haemolysin played a role in group II strains no matter whether infection occurred via the bladder or intravenously.

As to the importance of haemolysin in strains given intravenously, Smith (1963) found that preparations containing high concentrations of haemolysin were toxic for mice. Emödy et al. (1980) could not demonstrate a substantial difference between cultures producing haemolysin and their non-haemolytic derivatives in mice, and van den Bosch et al. (1981) also reported that haemolysin was not an important virulence factor in the extremely virulent group III strains which had a more general virulence for mice.

When haemolytic strains are given intraperitoneally (i.p.) or intranasally to 
mice, they are more toxic than non-haemolytic strains (Smith \& Linggood, 1971; Kéty et al. 1978; Emödy et al. 1980). Welch et al. (1981) compared the virulence of a strain into which the hly genes had been cloned with that of the same strain which had become $\mathrm{Hly}^{-}$after insertion of a transposon. When inoculated i.p. into rats, the $\mathrm{Hly}^{+}$strain was more virulent than the $\mathrm{Hly}^{-}$mutant. In a recent paper Smith \& Huggins (1985) showed that $\mathrm{Hly}^{+}$bacteria given i.p. to mice multiply and produce haemolysin, and when sufficient haemolysin has been liberated, the animals die. The transposon-inserted $\mathrm{Hly}^{-}$mutant of the strain also caused death of the mice, but not until the bacteria had multiplied to a much greater extent.

The mechanism and site of action of haemolysin is not yet known. Partially purified preparations of haemolysin from $E$. coli strains are cytotoxic for human leucocytes and for fibroblasts in vitro (Cavalieri \& Snyder, $1982 a-c)$. Gadeberg, Orskov \& Rhodes (1983) described a cell-associated toxic effect for human monocytes and granulocytes in haemolytic $E$. coli strains; this effect was not inhibited by autologous plasma, in contrast to the effect produced by haemolysincontaining culture supernatants. Isogenic $\mathrm{Hly}^{-}$bacteria were not cytotoxic (Gadeberg \& Ørskov, 1984). Thus a haemolytic $E$. coli culture may be virulent because of a toxic effect on various cells, and in addition this effect may be strengthened because the growth of the strain is stimulated by iron made available by lysis of the erythrocytes (Linggood \& Ingram, 1982; Waalwijk, MacLaren \& de Graaf, 1983). See also aerobactin under the section on bacteraemia.

\section{Serum resistance}

It has been claimed that the ability to resist the bactericidal activity of serum was present more often in pyelonephritis $E$. coli strains than in ABU strains (Gower et al. 1972; Olling et al. 1973; Björkstén \& Kaijser, 1978), and that it was significantly correlated with haemolysin production and with $\mathrm{O}$ types $\mathrm{O} 4, \mathrm{O} 6, \mathrm{O} 18$ and 075 (Hughes, Phillips \& Roberts, 1982). For further information on serum resistance see under bacteraemia.

\section{Phagocytosis}

$E$. coli with MS fimbriae/adhesins bind to and activate human polymorphonuclear leucocytes (PMV) (Bar-Sharit et al. 1977; Mangan \& Snyder, 1979; Silverblatt, Dreyer \& Schauer, 1979), while strains with MR fimbriae of the gal-gal recognizing type are poor in this respect (Blumenstock \& Jann, 1982; Svanborg Edén et al. 1984); this means that possession of these last-mentioned fimbriae may confer resistance to phagocytosis. For other information on phagocytosis see under bacteraemia.

\section{Adhesion and fimbriae}

Svanborg Edén et al. $(1976,1978)$ have shown that $E$. coli from cases of acute pyelonephritis in children adhere to human urinary epithelial cells to a greater extent than strains from cases of cystitis, and these latter strains adhere in higher number than strains from ABU. It was further demonstrated that the ability to adhere was strongly correlated with the presence of fimbriae and mannose-sensitive agglutination of guinea-pig erythrocytes; however, the adhesion to urinary epithelial cells was not inhibited by $\mathrm{D}$-mannose, suggesting that this adhesion 
might be mediated by some bacterial surface factor co-appearing with the fimbriae (Svanborg Edén \& Hansson, 1978). Källenius \& Möllby (1979) reported that adhesion to human periurethral cells correlated to mannose-resistant agglutination of human erythrocytes. A very high proportion of strains with those two abilities were present among acute pyelonephritis isolates from children, in contrast to the proportion among normal faecal $E$. coli as shown by Hagberg et al. (1981). The attachment is mediated by a specific binding to glycolipid receptors of the globoseries (Leffler \& Svanborg Edén, 1981), and fimbriae binding in this way have been termed GS fimbriae (Svanborg Edén et al. 1983a). The receptor is part of the $\mathrm{P}$ blood group antigen containing $\alpha$-D-galactose-( $\beta 1-4)$-D-galactose residues, and therefore the fimbriae have also been termed P fimbriae (Källenius et al. 1980, 1981). Another name is pap pili (pyelonephritis-associated pili) (Hull et al. 1981) or gal-gal pili (O'Hanley et al. 1985).

The view that gal-gal fimbriae are virulence factors in UTI has its opponents, however. Thus Harber et al. (1982) questioned the role played by fimbriae, since bacteria freshly shed in the urine of infected patients failed to bind to epithelial cells. As pointed out by Kunin (1982) and Svanborg Edén et al. (1982) an explanation might be that the patients in the series of Harber et al. (1982) had complex urologic problems, in which cases the bacteria do not need adhesive properties. This suggestion was strongly supported by the findings of Lomberg et al. (1984), who demonstrated a lower frequency of adhesiveness among strains from children with reflux than among those without reflux. Svanborg Edén et al. (1982) further suggested that the findings of Harber et al. (1982) might be due to the fact that not all bacteria in a culture attach to uroepithelial cells. It is therefore understandable that UTI patients shed non-adhering bacteria. The question has been raised why not all bacteria in a fimbriated culture are fimbriated (Ørskov et al. 1982b). An answer could be phase variation, a mechanism first described for type 1 fimbriae by Brinton, Buzzell \& Lauffer (1954). This explanation is supported by the recent report by Rhen, Mäkelä \& Korhonen (1983) and Nowicki et al. (1984), who showed that an extremely rapid phase variation takes place between different fimbrial types present in an $\mathrm{O} 4: \mathrm{K} 12$ strain.

\section{Receptor cells in adherence tests}

In vitro adherence experiments with UTI strains have mainly been carried out with epithelial cells from the sediment of the urine of healthy persons or with periurethral cells from healthy individuals (Svanborg Edén et al. 1976; Schaeffer, Amundsen \& Schmidt, 1979; Källenius, Möllby \& Winberg, 1980). No difference in receptivity between these types of cell has been reported. Buccal epithelial cells have also been used by some workers. Schaeffer et al. (1982) described a strong correlation between receptivity of vaginal and buccal cells, while Varian \& Cooke (1980) found that UTI strains adhered better to urinary epithelial cells than to buccal cells. UTI strains expressing only gal-gal fimbriae bind to both urinary and buccal cells, although the receptivity of buccal cells may be lower. However, many UTI strains express in addition to gal-gal fimbriae some fimbriae antigenically termed F1C (Ørskov \& Ørskov, 1983) with no haemagglutinating ability, and $E$. coli with only these last-mentioned fimbriae confer adherence to buccal cells but not to uroepithelial cells (Ørskov et al. 1982b). Since a single $E$. coli strain may 
express several kinds of fimbriae (Duguid \& Old, 1980; Jann, Jann \& Schmidt, 1981 ; Ørskov et al. $1982 b$; Korhonen et al. 1982), no conclusion about fimbriae and attachment to different epithelial cell types can be drawn until the fimbriae of the strains examined have been analysed.

\section{Serology of MR fimbriae}

Fimbriae present in UTI strains causing agglutination of human and monkey erythrocytes in a mannose-resistant manner (MRHA) were examined serologically by means of crossed immunoelectrophoresis (CIE), and different types received the F antigen numbers F 7-F 13 (Ørskov, Ørskov \& Birch-Andersen, 1980; Ørskov et al. 1982a, Ørskov \& Ørskov, 1985) (the F antigen numbering of all fimbriae regardless of morphology and receptor binding was suggested for practical reasons (Ørskov \& Ørskov, 1983)).

Test strains for F antigens F 7-F 13 all agglutinate gal-gal $(\mathrm{P})$ receptor-coated particles, although $\mathrm{F} 10$ less well than the others. There is almost no relationship between antigens F7-F13 when any two of those antigens are examined for cross-reaction against one antiserum in CIE. This type of examination was carried out by incorporation of a heterologous $\mathrm{F}$ antigen extract in the intermediate gel of each test $\mathrm{F}$ antigen CIE system. However, several of the antigens F 7-F 13 do cross-react when examined by another method in which a heterologous $\mathrm{F}$ antiserum is added to the intermediate gel instead of an $\mathrm{F}$ antigen extract, i.e. when one antigen is tested against two antisera (Ørskov \& Ørskov, 1983, 1985). Chemically these as well as the type 1 (see below) fimbrial antigens constitute a group of evolutionarily related proteins (Klemm, Ørskov \& Ørskov, 1983).

\section{Correlation of $F$ antigen and $O: K: H$ serotype}

By examination of the $\mathrm{F}$ antigens found in strains of the most common $\mathrm{O}: \mathrm{K}: \mathrm{H}$ serotypes among cystitis and pyelonephritis strains causing MRHA of human erythrocytes (Ørskov et al. 1982b; Ørskov \& Ørskov, 1983, 1985) an association was found between $\mathrm{F}$ antigen and $\mathrm{O}: \mathrm{K}: \mathrm{H}$ serotypes, a finding which was suggested to reflect nature's selection of certain virulent clones rather than genetic linkage of different structures (Ørskov et al. 1982a). The $\mathrm{O}: \mathrm{K}: \mathrm{H}: \mathrm{F}$ types are the following: $\mathrm{O} 1: \mathrm{K}: \mathrm{H}^{-}: \mathrm{F}, \mathrm{O} 1: \mathrm{K} 1: \mathrm{H} 7: \mathrm{F} 11, \mathrm{O} 2: \mathrm{K} 1: \mathrm{H} 4: \mathrm{F} 11, \mathrm{O} 4: \mathrm{K} 12: \mathrm{H} 1: \mathrm{F} \mathrm{11}$, F 12 related, O4:K 12:H 5:F 13, F 12 related and Fy (not yet characterized), O 6:K 2:H 1:F 7 (F $7_{1}$ and/or F $7_{2}$ ), O 7:K 1:H $\mathrm{H}^{-}: \mathrm{F} 10$ and $\mathrm{O} 16: \mathrm{K} \mathrm{1:H} \mathrm{6:F} \mathrm{12,}$ some in addition $\mathrm{F} 11$.

$\mathrm{F}$ antigen $1 \mathrm{C}$ which does not cause haemagglutination is present in many UTI strains, but has been left out from the $\mathrm{O}: \mathrm{K}: \mathrm{H}: \mathrm{F}$ serotype formula given here.

It is noteworthy that the typical cystitis serotype $06: \mathrm{K} 13: \mathrm{H} 1$ does not have MRHA activity (Ørskov et al. 1982b).

E. coli serotype $06: \mathrm{K} 5: \mathrm{H} 1$ are among strains isolated from cystitis or pyelitis. Some of these strains adhere to uroepithelial cells, but the adhesin has not yet been classified antigenically. Tullus et al. (1984) have recently reported that $\mathrm{P}$ (galgal)-fimbriated $06: \mathrm{K} 5$ strains caused epidemic outbreaks of acute pyelonephritis in children less than 2 years old by nosocomial spread in a neonatal ward.

The MRHA capacity and adherence of strains belonging to the above-mentioned frequent UTI serotypes is ascribed to the gal-gal recognizing fimbriae, but may 
in some cases also be due to adhesins not recognizing the gal-gal receptors. This may, for example, be the case in $07: \mathrm{K} 1: \mathrm{H}^{-}$strains, in which $\mathrm{F} 10$ is not invariably present. The test strain of the $\mathrm{F} 10$ antigen is of this $\mathrm{O}: \mathrm{K}: \mathrm{H}$ type and recognizes gal-gal receptor-coated particles, but not so strongly as the test strain of antigens F 7, F8, F9, F11, F12 and F13.

It has been reported that strains of $O$ group 2 possess adhesins that recognize the amino-terminal part of glycophorin A on human blood group $M$ erythrocytes (Väisänen et al. 1982) and that $\mathrm{O} 2: \mathrm{K} 1$ and $\mathrm{O} 18: \mathrm{K} 1$ strains possess fimbria recognizing sialyl-galactosides (Parkinen et al. 1983; Korhonen et al. 1984). Such adhesins are occasionally present in UTI strains (Väisänen-Rhen et al. 1984) and have been termed $\mathrm{M}$ and $\mathrm{S}$ fimbriae, respectively (Korhonen et al. 1984). No report has appeared regarding the adherence of such strains to urinary epithelial cells. Strains of $\mathrm{O}$ group 75 also with MRHA activity for human erythrocytes are not infrequently present among UTI strains (Ørskov \& Ørskov, 1982b; Väisänen-Rhen et al. 1984). A non-P (gal-gal), $\mathrm{M}$ or $\mathrm{S}$ haemagglutinin provisionally termed $\mathrm{O} 75 \mathrm{X}$, of coil-like structure, has been demonstrated in $075: \mathrm{K} 5: \mathrm{H}$ - strains isolated from UTI and normal faeces (Väisänen-Rhen, 1984).

Non-fimbrial, non-gal-gal binding adhesins causing MR haemagglutination of human erythrocytes have recently been shown in a pyelonephritic $E$. coli of $O$ group $\mathrm{O} 2$ (Labigne-Roussel et al. 1984) and in a urinary strain of serotype O 83:K $1: \mathrm{H} 4$ (Goldhar, Perry \& Ofek, 1984). Furthermore a non-gal-gal binding adhesive protein capsule consisting of exceedingly fine filaments was demonstrated in three $E$. coli strains, one of which was an $\mathrm{O} 21: \mathrm{K} 7: \mathrm{H} 4 \mathrm{UTI}$ isolate (Ørskov et al. 1985). The importance of these adhesins is not known yet.

\section{MS fimbriae (type 1)}

Most $E$. coli strains are capable of producing type 1 fimbriae mediating a mannose-reversible (MR) binding capacity (Duguid \& Gillies, 1957) and thus also UTI strains with MR adhesins have this capacity. These MS fimbriae bind to monkey kidney cells (Salit \& Gotschlich, 1977) and to rat uroepithelial cells (Korhonen, Leffler \& Svanborg Edén, 1981). Binding to human uroepithelial cells has been described (Schaeffer, Amundsen \& Schmidt, 1979; van den Bosch et al. 1981), but it has also been reported that most strains with MSHA adhere poorly to human uroepithelial cells, and that if they attach they attach only to squamous cells, not to transitional cells, in contrast to those with MRHA activity of the gal-gal binding type (Hagberg et al. 1981). However, Ørskov, Ørskov \& Birch-Andersen (1980) demonstrated that strains with type 1 fimbriae specifically adhere to urinary mucus, which was shown to be identical to Tamm Horsfall protein (Ørskov, Ferenz \& Ørskov, 1980), and these authors suggested that trapping of type 1 fimbrial bacteria by the mucus could be considered as a non-immune resistance mechanism. The binding of type 1 fimbriae to urinary mucus (alias Tamm Horsfall protein), has been confirmed by Chick et al. (1981).

\section{Role of adhesion for experimental infection}

The role of MS and MR (gal-gal) fimbriae for reproduction of disease has been studied in mice, since both kinds of fimbriae attach to mouse uroepithelial cells, while rat cells bind only MS fimbriae (Hagberg et al. 1983a). About $10^{10}$ bacteria 
were installed into the bladder through a polyethylene catheter. The animals were sacrificed at different times after infection, and viable counts were performed on homogenized bladders and kidneys. The strains used were mutants of an 075 strain isolated from a case of acute pyelonephritis expressing either MS or MR or both kinds of fimbriae, or transformants obtained by cloning genes from strain J96 (O4:K6) coding for either the MS or the MR fimbriae into a normal faecal strain (O16:K1) or into 'K 12' (Hagberg et al. 1983b; Svanborg Edén et al. 1983b). Presence of MR fimbriae enhanced bacterial recovery from both kidneys and bladders, while mutants and transformants with MS fimbriae were recovered in larger numbers from the bladders than those expressing the MR fimbria, but seemed to give little advantage in the kidney. The transformants derived from both the rough $\mathrm{K} 12$ strain and the smooth faecal strain $(016: \mathrm{K} 1)$ adhered in vitro as well as or better than the mutants derived from a pyelonephritis isolate. Yet the transformants were at a significant disadvantage in vivo, i.e. adhesive capacity adds to infectivity in bacteria with other virulence factors but is insufficient to confer virulence as such. Also O'Hanley et al. (1985) compared the pathogenic significance of MS and MR (gal-gal) fimbriae in the mouse model and cloned from strain J96 the genetic determinant for these fimbriae into a K12 strain. No colonization of the renal pelvis took place after installation of $10^{6}$ bacteria of the MS clone, while administration of $10^{10}-10^{12}$ MS bacteria resulted in acute ureteric reflux and colonization of the kidneys. In contrast only $10^{6}$ of the cloned bacteria expressing MR fimbriae colonized the kidneys. Since a titratable factor in the urine identical to Tamm Horsfall protein bound to MS fimbriae, it was suggested that the reason why the MS clone did not mediate renal colonization when inocula $\leqq 10^{8}$ bacteria were installed, was that the binding capacity for cell-surface receptor molecules present in the mice epithelial cells was nullified by the Tamm Horsfall protein, and this effect could be overcome when larger doses were given.

\section{NEONATAL MENINGITIS: O AND K ANTIGEN}

$E$. coli is a major cause of neonatal meningitis, and $E$. coli meningitis has a high mortality rate and frequency of sequelae (Robbins et al. 1974a; Mulder \& Zanen, 1984). Robbins et al. (1974a), McCracken et al. (1974) and Sarff et al. (1975) showed that $84 \%$ of $E$. coli isolated all over the U.S.A. from patients with this disease carried the K 1 antigen. Similar high frequencies of K 1-carrying strains have been found in Europe (Cheasty, Gross \& Rowe, 1977; Mulder \& Zanen, 1984; Mulder, van Alphen \& Zanen, 1984). K1 strains are found frequently but with lower frequencies in faeces of infants and adults (Robbins et al. 1974a; Sarff et al. 1975; Ørskov \& Ørskov, 1975). The most frequent $\mathrm{O}$ groups associated with $\mathrm{K} 1$ among American strains were O7, O18, O1 and O6 (Robbins et al. 1974a; McCracken et al. 1974), and the same $O$ groups are found in European strains from neonatal meningitis. However, at least one $\mathrm{O}$ group, $\mathrm{O} 83$, which is highly prevalent in continental Europe (Handrück et al. 1982; Mulder, van Alphen \& Zanen, 1984), has only rarely been found in the U.S.A. Based on these results, it was natural to call the $\mathrm{K} 1$ antigen a virulence factor. The $\mathrm{K} 1$ antigen and the capsular polysaccharide of Neisseria meningitidis type B are chemically and immunologically 
very similar (Grados \& Ewing, 1970; Robbins et al. 1974b): both are linear homopolymers of an $\alpha 2-8$ linked $N$-acetyl neuraminic acid (NANA) (Barry \& Goebel, 1957; Bolanos \& de Witt, 1966). The K 1 antigen is a poor immunogen in rabbits when injected intravenously as live organisms. High-titred capsular antisera can, however, be obtained with formalinized $N$. meningitidis group B organisms by repeated immunization of horses, and antiserum from one horse (no. 46) is used currently in many laboratories as an anti-K 1 serum. The antiserum agar technique (Sarff et al. 1975) that has been used widely to screen for $E$. coli $\mathrm{K} 1$ is based on the finding that a precipitation halo will develop around colonies when $\mathrm{K} 1$ cultures are grown on $\mathrm{K} 1$ antiserum-containing plates. Gross, Cheasty \& Rowe (1977) have isolated a small series of K 1 -specific phages that are used in many laboratories for $\mathrm{K} 1$ detection. Practically all $\mathrm{K} 1$ cultures will give rise to colonies of two forms determined by the presence of $\mathrm{O}$-acetylated $\left(\mathrm{OAc}^{+}\right)$or non-O-acetylated $\left(\mathrm{OAc}^{-}\right) \mathrm{K} 1$ polysaccharide. Either type of colony will give rise to colonies of both types when subcultured (Ørskov et al. 1971, 1979). This type of variation was called form variation, in analogy to the form variation described in salmonella $\mathrm{O}$ antigens (Kauffmann, 1940). The $\mathrm{OAc}^{+} \mathrm{K} 1$ polysaccharide is resistant to hydrolysis by neuraminidases (Ørskov et al. 1979) and is more immunogenic in rabbits than the $\mathrm{OAc}^{-}$polysaccharide. Most cultures from neonatal meningitis and from other sources are found predominantly in the $\mathrm{OAc}^{-}$ state when first examined; at present, however, no conclusion can be drawn about the possible influence of form variation in natural disease. The genetic background for the form variation phenomenon has been investigated by Silver, Vann \& Aronson (1984).

The occurrence of the same capsular polysaccharide in two different pathogens causing bacterial meningitis, the coli $\mathrm{K} 1$ antigen and the group B antigen of $N$. meningitidis, has led to speculation about the importance of such cross-reacting antigens in 'natural immunity' to meningococcus B disease (Robbins et al. 1974b). The common occurrence of K1 strains in the healthy intestine speaks for this possibility, while the poor immunogenicity of the K 1 antigen speaks against it (Robbins et al. 1974b; Ørskov et al. 1979). Another pair of such cross-reacting antigens is the Haemophilus influenzae type b capsule and the coli $\mathrm{K} 100$ antigen that are both polyribitol phosphates (Schneerson et al. 1972; Robbins et al. 1976). $E$. coli $\mathrm{O} 75: \mathrm{K} 100$ fed to adult volunteers caused significant rises in anti-capsular antibodies, and the not infrequent occurrence of $E$. coli with the K 100 antigen might well explain the occurrence of antibodies to $H$. influenzae type $\mathrm{b}$ antigen in the adult population (Robbins et al. 1973). Other examples of antigenic cross-reactions between coli $\mathrm{K}$ antigens and the capsular antigens of invasive bacteria have been described by Robbins et al. (1974b).

\section{BACTERAEMIA}

Neonatal meningitis with $E$. coli is most likely preceded by a bacteraemic phase, and several investigators count strains from neonatal meningitis and bacteraemia as one group. E. coli septicaemia and bacteraemia do not occur only in neonates, and most published bacteraemia materials contain strains from all age groups. The 
strains described in such studies arrived in the blood from many different sites of infection; especially frequently, however, from the urinary tract (Kreger et al. 1980). Many strains came from immunocompromised patients.

\section{$O$ antigens}

Several groups of investigators have examined bacteraemia strains for their $\mathrm{O}$ antigens. Vosti et al. (1964) found $\mathrm{O}$ groups $\mathrm{O} 6, \mathrm{O} 4, \mathrm{O} 1, \mathrm{O} 75, \mathrm{O} 50, \mathrm{O} 16, \mathrm{O}$ 7, $\mathrm{O} 21$, $\mathrm{O} 17$ and $\mathrm{O} 18$, in that order of frequency. Maiztegui et al. (1965) presented a very similar list of frequent $O$ groups. McCabe et al. (1978) found in another large body of US data that $\mathrm{O}$ groups $\mathrm{O} 6, \mathrm{O} 4, \mathrm{O} 2, \mathrm{O} 16, \mathrm{O} 18$ and $\mathrm{O} 7$ were found frequently in both adult and infant bacteraemia, and that no significant difference could be found between the occurrence of the single $O$ groups in the two groups of patients. Ørskov \& Ørskov (1975), who examined 559 strains from different places in Denmark, found the following order of frequency: O 2, O4, O6, O 75, 09, O8, O18, $\mathrm{O} 7, \mathrm{O} 22$ and $\mathrm{O} 1$. Antisera corresponding to the most common $\mathrm{O}$ groups could classify $57 \%$ of the strains. Cross et al. (1984), who examined a large collection of material from Washington D.C., found that $\mathrm{O}$ groups O6, O4, O1, O18ac, O16, $\mathrm{O} 75, \mathrm{O} 8, \mathrm{O} 2, \mathrm{O} 12$ and $\mathrm{O} 15$ were the most frequent ones and made up $59 \%$ of all strains. Thus, even though minor differences among these materials from various geographical areas could be found, the uniformity of results is impressing. Most of these $\mathrm{O}$ groups are also found frequently in other types of extra-intestinal infections, but in addition in the normal healthy intestine - much more rarely however - and one can therefore not conclude from these results that some $\mathrm{O}$ group strains have special invasive capacities. This 'special pathogenicity' versus 'prevalence'discussion has already been treated above (in the UTI section).

\section{$K$ antigens and $O: K: H$ serotypes}

McCabe et al. (1978) also carried out $\mathrm{K}$ determination on their strains and found $\mathrm{K}$ antigen in the following order of frequency: K 1, K 2, K 12, K 3, K 13, K 15, K 8 and K 52. Because of lack of a useful antiserum, K5 determination was not carried out. Among strains that could be typed for both $\mathrm{O}$ and $\mathrm{K}$ antigen they found the following $\mathrm{O}: \mathrm{K}$ combinations to be the most common: $\mathrm{O} 16: \mathrm{H} 1, \mathrm{O} 6: \mathrm{K} 2, \mathrm{O} 1: \mathrm{K} 1$, $018: \mathrm{K} 1, \mathrm{O} 4: \mathrm{K} 12$ and $\mathrm{O} 7: \mathrm{K} 1$. We have recently examined the above-mentioned Danish material in more detail (Ørskov \& Ørskov, in preparation) and found that the most frequent $\mathrm{K}$ antigens were: $\mathrm{K} 1, \mathrm{~K} 12, \mathrm{~K} 5, \mathrm{~K} 13, \mathrm{~K} 2$, K 15, K 52 and $\mathrm{K} 25$, in that order. Amongst $363 \mathrm{O}$ groupable strains $156 \mathrm{O}: \mathrm{K}: \mathrm{H}$ serotypes were found; 97 of these were represented by only one strain, whilst some serotypes were represented by many strains: $\mathrm{O} 4: \mathrm{K} 12: \mathrm{H} 5$ by 28 strains, $\mathrm{O} 2: \mathrm{K} 1: \mathrm{H} 4$ by 14 and $\mathrm{O} 6: \mathrm{K} 15: \mathrm{H} 31$ by 8 strains. Some of these frequent $\mathrm{O}: \mathrm{K}: \mathrm{H}$ serotypes found in this Danish material have also been found among blood isolates in other locations. Evans et al. (1981), who examined a large number of blood isolates with special attention to the association between haemagglutination, haemolysin production and serotype, also found these $\mathrm{O}: \mathrm{K}: \mathrm{H}$ serotypes well-represented. Korhonen et al. (1985) found that $\mathrm{O} 18 \mathrm{ac}: \mathrm{K} 1: \mathrm{H} 7, \mathrm{O} 7: \mathrm{K} 1: \mathrm{H} 1, \mathrm{O} 6: \mathrm{K} 2: \mathrm{H} 1$ and Rough:K $1: \mathrm{H} 33$ altogether counted for $33 \%$ of 63 Finnish strains from infants blood. Cross et al. (1984) found $\mathrm{O} 18 \mathrm{ac}: \mathrm{K} 1, \mathrm{O} 1: \mathrm{K} 1$ and $\mathrm{O} 16: \mathrm{K} 1$ to be the most common $\mathrm{O}: \mathrm{K}$ types in the above-mentioned material from a Washington DC hospital. Thus, even 
though complete $\mathrm{O}: \mathrm{K}: \mathrm{H}$ serotyping has not been published from all studies based on American strains, it is most likely that it really is the same serotypes that are found frequently in blood in USA and in Scandinavia; O16:K1 may be an exception, being highly prevalent in American blood isolates and not at all represented among the published results based upon Scandinavian strains. As we know that O16:K 1 strains can be found in Denmark (data not published), we can only guess if this difference is based on an unexplained different prevalence in the intestine of the general population or if the US O16:K 1 serotypes carry special virulence factors. When discussing serotype distribution in different geographical locations, one could mention that Mabeck, Ørskov \& Ørskov (1971a), who examined UTI strains in a certain area, found unexplained changes in the prevalence of the serotype $\mathrm{O} 2: \mathrm{K} 1: \mathrm{H} 4$ over a three year period.

\section{Bactericidal serum activity}

Sjöstedt (1946), who examined isogenic capsulated and non-capsulated variants of well-defined $\mathrm{O}: \mathrm{K}: \mathrm{H}$ serotypes, noted that in $25 \%$ of strains the capsulated forms were the more serum resistant ones. The only two $\mathrm{K} 1$ strains examined fell in this group; many strains belonging to $\mathrm{O} 8$ and 09 with $\mathrm{K}$ antigens of the $\mathrm{A}$ type showed no serum resistance. He also compared serum resistance and toxicity measured in LD50 experiments on intraperitoneally infected mice and found that no correlation could be shown between toxicity and serum resistance. He concluded from the examination of many isolates that strains with the same $\mathrm{O}: \mathrm{K}: \mathrm{H}$ serotype had the same resistance to the bactericidal properties of blood. Glynn \& Howard (1970) quantitated $E$. coli $\mathrm{K}$ antigens by the ability of saline extracts to inhibit the agglutination of sheep erythrocytes in anti-erythrocyte serum. They found that $\mathrm{K}$-rich strains defined by this method were more resistant to serum killing that $\mathrm{K}$-poor ones. McCabe et al. $(1975,1978)$ detected no differences in serum resistance among strains with different $\mathrm{K}$ antigens from a collection of blood isolates. Taylor (1976) saw no correlation between susceptibility to serum killing and the amount of K antigen in a series of urinary strains. Van Dijk et al. (1979) came to very similar conclusions after examination of blood and faecal strains.

Taylor \& Robinson (1980) found that the genetic transfer of the his linked genes for the K 27 antigen did not change the sensitivity of recipients, and later Opal, Cross \& Gemski (1982) confirmed this finding. Based on the above reports it can therefore be concluded that many acidic $\mathrm{K}$ antigens have little or no role in protection against serum killing. On $\mathrm{K}$ antigen, $\mathrm{K} 1$, has a unique position because of its close association with cases of neonatal meningitis (see above). While Olling (1977) and Björkstén et al. (1976) could find no simple correlation between occurrence or amount of K 1 antigen in elinical isolates, Stevens et al. (1978) found that K 1 antigen inhibited complement activation. Cross et al. (1984), who examined a large collection of strains from blood, reported that $95 \%$ of the strains were serum resistant and related this ability to the presence of $\mathrm{K} 1$ and other $\mathrm{K}$ antigens; $\mathrm{K} 1$ was by far the most common $\mathrm{K}$ antigen. Many such $\mathrm{K} 1$ strains had a rough lipopolysaccharide at the same time; in this respect $\mathrm{K} 1$ strains were unique, as a common association between a degraded LPS and other K antigens could not be found. Silver et al. (1981) cloned the K 1 genes into a K 12 host and found that the recipient $\mathrm{K} 12$ strain expressing the $\mathrm{K} 1$ polysaccharide was resistant to serum 
killing. Timmis et al. (1981) found in similar cloning experiments that K 12 recipients of $\mathrm{K} 1$ were resistant to serum killing at low concentrations of serum, but not at higher concentrations. Stevens et al. (1978) and Pluschke et al. (1983) showed that the sialic acid containing $K 1$ capsule inhibited the activation of the alternative complement pathway. It is probably not possible to draw any definite overall conclusion about the role of acidic capsular polysaccharides in serum killing. The $\mathrm{K}$ antigens of the A type, i.e. the electrophoretically slow moving high molecular K antigens (Ørskov et al. 1977), which in several respects resemble klebsiella capsular antigens, probably have no major influence on serum killing. The scanty and contradictionary evidence about the electrophoretically fast moving, low molecular K antigens - except K 1 - does not allow us to say if some such $\mathrm{K}$ antigens may show a similar inhibitory activity.

The role of lipopolysaccharides as a protective factor against serum killing is more thoroughly examined. McCabe et al. (1978) found that strains with $\mathrm{O} 2$, O4, $\mathrm{O} 6, \mathrm{O} 7$ and $\mathrm{O} 18$ were the most serum resistant ones in a large collection from blood. Taylor (1974) described $\mathrm{O6}, \mathrm{O} 7$ and $\mathrm{O} 18$ strains as basically serum resistant, while strains with $\mathrm{O} 1, \mathrm{O} 2, \mathrm{O4}, \mathrm{O} 9$ and $\mathrm{O} 75$ were serum sensitive. Henkel (1970) found no correlation between serum resistance and $O$ groups. Taylor (1976) could not detect differences in the amount of extractable lipopolysaccharide from smooth urinary strains that differed in sensitivity to serum. It is, however, a well established fact that smooth to rough mutation, which determines a loss of polysaccharide side chains of the lipopolysaccharide, will also cause a change from serum resistance to serum sensitivity (Rowley, 1968; Taylor, 1975).

Recently Goldman, Joiner \& Leive (1984) described a serum-resistant strain of $E$. coli, O 111, derived from a serum-sensitive one, that had longer LPS side chains and also a more extensive coverage of the lipid A core subunits, thus supporting the view that the polysaccharide structure and the distribution of LPS, and especially the LPS side chains on the bacterial surface, is of major importance for the sensitivity to the bactericidal forces of serum (Taylor, 1983; Grossman \& Leive, 1984). Pluschke \& Achtman (1984) have compared serum sensitivity of O 18:K 1, $\mathrm{O} 7: \mathrm{K} 1$ and $\mathrm{O} 1: \mathrm{K} 1$ strains and related the findings to the diseases from which they were commonly isolated. They pointed out that $\mathrm{O} 18: \mathrm{K} 1$ and $\mathrm{O} 7: \mathrm{K} 1$ strains typically were serum resistant and associated with septicaemia and neonatal meningitis, while $01: \mathrm{K} 1$ strains were usually serum sensitive and rarely found in blood or in cerebrospinal fluid. Serum sensitivity was due to activation of the classical pathway. K 1 strains of all three $O$ groups were protected against activation of the alternative complement pathway. In contrast to $07: \mathrm{K} 1$ and O18: K 1 strains, $\mathrm{O} 1: \mathrm{K} 1$ strains could be killed by the classical pathway without application of $\mathrm{O}$ antibodies; differences in the structure of $\mathrm{O}$ antigens are probably partly responsible. Using $\mathrm{K} 1$ isolates of the same three $\mathrm{O}$ groups, Pluschke et al. (1983) found that $\mathrm{O} 7: \mathrm{K} 1$ and $\mathrm{O} 18: \mathrm{K} 1$ were able to cause bacteraemia in newborn rats, while $\mathrm{O} 1: \mathrm{K} 1$ strains could not. Disease and stool isolates did not differ in virulence, confirming Sjöstedt's (1946) old observations.

Taylor \& Parton (1976) described an outer membrane protein with influence on serum sensitivity which was only functional in strains with full development of lipopolysaccharide side chains. Plasmid-determined factors with an influence on serum killing have been described by several investigators and have been reviewed 
extensively by Taylor (1983). One example is the 25 -kd tra protein coded for by the R6-5 plasmid found in about 2100 copies per cell in the outer surface of the outer membrane, which will increase the survival in rabbit serum of a moderately serum sensitive $E$. coli strain (Moll, Manning \& Timmis, 1980). The modification of serum killing caused by such proteins can most clearly be demonstrated in moderately sensitive strains when using low concentrations of serum. Their existence underlines the multi-factorial nature of the resistance of bacteria to the bactericidal forces of serum.

\section{Phagocytosis}

Theobald Smith (1927) demonstrated that calf polymorphonuclear leucocytes were inactive against capsulated $E$. coli, while acapsular variants were readily taken up. Sjöstedt (1946) examined many well-defined $\mathrm{O}: \mathrm{K}: \mathrm{H}$ serotypes and also several sets of isogenic capsulated and non-capsulated $E$. coli. He found some correlation between serotype and phagocytosis and also that the capsulated form was resistant to phagocytosis in contrast to the acapsular variant. Serotypes with well-developed capsules, i.e. strains that gave capsular swelling with $\mathrm{K}$ antiserum, were never phagocytosed. Such strains would probably today be found to have $\mathrm{K}$ antigens of the A type and $\mathrm{O}$ antigens $\mathrm{O} 8,09, \mathrm{O} 20$ or $\mathrm{O} 101$ (Ørskov et al. 1977). Sjöstedt (1946) also found that strains belonging to $\mathrm{O} 1: \mathrm{K} 1: \mathrm{H} 1$, and especially to $\mathrm{O6}: \mathrm{K} 13: \mathrm{H}^{-}$, would readily undergo phagocytosis; in fact all strains with $\mathrm{O} 6$ were easily phagocytosed, while other serotypes would be phagocytosed to a differing degree. Specific $\mathrm{O}$ antisera did not increase phagocytosis, while $\mathrm{K}$ antibodies, did, according to Sjöstedt (1946).

Weinstein \& Young $(1976,1978)$ found that K1-containing strains from bacteraemia were relatively more resistant to opsonophagocytosis by normal human plasma and polymorphonuclear leucocytes than non-K 1 strains. Addition of $\mathrm{K}$ antibody increased the phagocytosis of $\mathrm{K} 1$ bacteria, and the authors suggested that the low immunogenicity of the K1 antigen could explain the resistance to phagocytosis in normal plasma. K 1-bearing bacteria from stools showed the same degree of phagocytosis when compared with blood isolates. Stevens, Chu \& Young (1980) found that the degree of phagocytosis of K 1 strains was inversely related to the amount of capsular antigen. They described an additional sialic acid containing $\mathrm{K} 1$-related antigen that was found in the greatest amount in strains that were more readily phagocytosed. Bortolussi et al. (1979) showed that the $\mathrm{K} 1$ antigen protected the $\mathrm{K} 1$ strains against opsonization by the alternative pathway and further that strains with much cell-associated $K$ antigen were more resistant to phagocytosis and more virulent in newborn rats than strains with little capsular polysaccharide. Cross et al. (1984) found similarly that the K 1 antigen protected against opsonophagocytosis by normal human serum and neutrophils, and, in contrast to some earlier observations cited above, they found that most other $\mathrm{K}$ antigens did not offer any protection against phagocytosis. Thus at the present time more investigation is needed on the role of coli $\mathrm{K}$ antigens other than K 1 - in phagocytosis. 


\section{Haemolysin}

The observation that many $E$. coli strains from septicaemia are haemolytic has been made by many investigators: Minchew et al. (1978), De Boy, Wachsmuth \& Davis (1980), Evans et al. (1981), Korhonen et al. (1985). For more details about the haemolysins as virulence factors see above under UTI.

\section{Aerobactin}

Minchew et al. (1978), who showed an association of haemolysin production, haemagglutination of human erythrocytes and virulence for chicken embryos in extra-intestinal $E$. coli isolates, further found that $12 \%$ of their blood isolates carried the colicin V plasmid (Col V). Quackenbush \& Falkow (1979) found, however, that the common occurrence of the Col V plasmid in invasive $E$. coli did not imply that Col $\mathrm{V}$ had any influence on the virulence of such strains. Smith \& Huggins (1980) showed that the loss of any of the characters $\mathrm{O}, \mathrm{K}$ or Col V from an $\mathrm{O} 18: \mathrm{K} 1: \mathrm{H} 7 \mathrm{Col} \mathrm{V}$ carrying $E$. coli would make the strain less virulent for chickens and mice than the parent form. However, the transfer of any or all of these virulence markers to a $\mathrm{K} 12$ strain would only bring minor increases in virulence to the original $\mathrm{K} 12$ strain. The loss of virulence of the variants of the O 18: K 1:H 7, Col V strain was caused by a decreased ability to invade the body. Williams (1979) and Warner et al. (1981) showed that Col V carrying $E$. coli produced a Col V plasmid-determined siderophore, which was chemically a hydroxymate compound identical to aerobactin, originally described in 'Aerobacter aerogenes or Klebsiella' by Gibson \& Magrath (1969). Similar findings were reported by Braun (1981). Valvano \& Crosa (1984) found that the gene determining aerobactin-production can be chromosomal in $\mathrm{K} 1$ antigen-carrying strains. The ability to multiply in blood and tissue is dependent on the availability of iron for the support of bacterial growth. Aerobactin and other iron-binding compounds in association with haemolysis could therefore be looked upon as highly important synergistic virulence factors.

\section{Adhesins}

Presence of adhesins in strains from sepsis and meningitis has not been examined as extensively as it has in those from UTI. It is known that $06: \mathrm{K} 2: \mathrm{H} 1$ and $04: \mathrm{K} 12: \mathrm{H} 5$ strains from blood have the same fimbrial antigens as the UTI strains of these serotypes (Ørskov \& Ørskov, 1983); however, Korhonen et al. (1985) have reported that $06: \mathrm{K} 2: \mathrm{H} 1$ and $\mathrm{O} 7: \mathrm{K} 1: \mathrm{H}$ - strains from neonatal sepsis or meningitis apart from the gal-gal binding fimbriae also produced $\mathrm{X}$ adhesins, i.e. adhesins not identified as type 1, gal-gal (P), S or M fimbriae, and furthermore that most of the O18:K1:H7 strains from such cases had no gal-gal fimbriae but $S$ fimbriae, i.e. those recognizing sialyl galactosides. For further details regarding adhesins see under UTI strains.

\section{CONCLUSION}

The Escherichia coli species consists of a bewildering number of stable phenotypes. The highly selected strains received in Copenhagen since 1950 (more than 30000 strains) belong to several thousand different serotypes, not to speak of the much 
higher number of bio-serotypes or more highly defined phenotypes into which they could be subdivided.

It is therefore consoling for the medically orientated person that recent times have seen a revival of the ideas which were put forward many years ago (Sjöstedt, 1946), i.e. that each well-defined $O: K: H$ serotype had a characteristic pathogenic capacity, and that the number of virulent serotypes was quite restricted. The possibility that such well-defined $\mathrm{O}: \mathrm{K}: \mathrm{H}$ serotypes might represent bacterial clones was suggested by Ørskov et al. (1976), based on investigations on enterotoxigenic E. coli (ETEC) isolated all over the world. This clone concept was also proposed as an explanation for the non-random occurrence of serobiotypes $\mathrm{O} 18 \mathrm{ac}: \mathrm{K} 1: \mathrm{H} 7, \mathrm{O} 1: \mathrm{K} 1: \mathrm{H} 7$ and $\mathrm{O} 16: \mathrm{K} 1: \mathrm{H} 6$ in strains from blood and faeces (Myerowitz et al. 1977). Achtman et al. (1983) introduced the analysis of outer membrane proteins (OMP) and Caugant et al. (1981) the iso-enzyme analysis, both important for a detailed clone definition.

The pathogenic phenotypes are characterized by certain virulence factors; however, a single trait is not enough to cause virulence, several traits must act in concert.

Recent investigations also indicate that not only do some special clones, that often can be described by the sero-biotype, have a special virulence, but it is also apparent that disease like neonatal meningitis, non-neonatal bacteraemia and pyelonephritis, i.e. diseases with different locations in the human body, are sometimes connected with special types characteristic for each disease location.

We are most grateful for the never-failing care and enthusiasm with which our secretary Mrs Bente Hansen has helped us to complete the manuscript for this paper.

\section{REFERENCES}

Achtman, M., Mercer, A., Kusecek, B., Pohl, A., Heuzenroeder, M., Aronson, W., Sutton, A. \& Silver, R. P. (1983). Six widespread clones among Escherichia coli $\mathrm{K} 1$ isolates. Infection and Immunity 39, 315-335.

Bar-Sharit, Z., Ofek, I., Goldman, D., Mirelman, D. \& Sharon, N. (1977). Mannose residues on phagocytes as receptors for the attachment of Escherichia coli and Salmonella typhi. Biomedical and Biophysical Research Communication 78, 455-460.

Barry, G. T. \& Goebel, W. F. (1957). Colominic acid, a substance of bacterial origin related to sialic acid. Nature (London) 179, 206-208.

Bergström, T., Lincoln, K., Ørskov, F., Ørskov, I. \& Winberg, J. (1967). Studies of urinary tract infections in infancy and childhood. Journal of Pediatrics 71, 13-20.

Bettelheim, K. A. \& Taylor, J. (1969). A study of Escherichia coli isolated from chronic urinary infections. Journal of Medical Microbiology 2, 225-236.

Bü̈rkstén, B., Bortolussi, R., Gothefors, L. \& Quie, P. G. (1976). Interaction of E. coli strains with human serum: Lack of relationship to K1 antigen. Journal of Pediatrics 89, 892-899.

BJÖRKSTÉN, B. \& KAIJSER, B. (1978). Interaction of human serum and neutrophils with Escherichia coli strains: difference between strains isolated from urine of patients with pyelonephritis or asymptomatic bacteriuria. Infection and Immunity 22, 308-311.

BLUMENSTOCK, E. \& JaN , K. (1982). Adhesion of piliated Eschericia coli strains to phagocytes: difference between bacteria with mannose-sensitive pili and those with mannose-resistant pili. Infection and Immunity 35, 264-269.

Bolanos, R. \& DE WITT, C. W. (1966). Isolation and characterization of the K 1 (L) antigen of Escherichia coli. Journal of Bacteriology 91, 987-996. 
Bollgren, I. \& Winberg, J. (1976). The periurethral aerobic bacterial flora in girls highly susceptible to urinary infections. Acta Paediatrica Scandinavica 65, 81-87.

Bortolussi, R., Ferrieri, P., Buörkstén, B. \& Quie, P. B. (1979). Capsular K 1 polysaccharide of Escherichia coli. Relationship to virulence in newborn rats and resistance to phagocytosis. Infection and Immunity 25, 293-298.

BraUn, V. (1981). Escherichia coli cells containing the plasmid Col V produce the iron ionophore aerobactin. FEMS Microbiology Letters 11, 225-228.

Brinton, C. C., JR, Buzzell, A. \& Lauffer, M. A. (1954). Electrophoresis and phage susceptibility studies on a filament-producing variant of the $E$. coli $\mathrm{B}$ bacterium. Biochemical and Biophysical Acta 15, 533-542.

Brooks, H. J. L., O’Grady, F., McSherry, A. \& Cattell, W. R. (1980). Uropathogenic properties of Escherichia coli in recurrent urinary tract infection. Journal of Medical Microbiology 13, 57-68.

Caugant, D. A., Levin, B. R. \& Selander, R. K. (1981). Genetic diversity and temporal variation in the $E$. coli population of a human host. Genetics $98,467-490$.

Cavalieri, S. J. \& SNYDer, I. S. (1982a). Cytotoxic activity of partially purified Escherichia coli alpha haemolysin. Journal of Medical Microbiology 15, 11-21.

Cavalieri, S. J. \& SNY Der, I. S. (1982b). Effect of Escherichia coli alpha-hemolysin on human peripheral leucocyte viability in vitro. Infection and Immunity 36, 455-461.

Cavalieri, S. J. \& SNYDER, I. S. (1982c). Effect of Escherichia coli alpha-hemolysin on human peripheral leucocyte function in vitro. Infection and Immunity 37, 966-974.

Cheasty, T., Gross, R. J. \& Rowe, B. (1977). Incidence of K 1 antigen in Escherichia coli isolated from blood and cerebrospinal fluid of patients in the United Kingdom. Journal of Clinical Pathology 30, 945-950.

Chick, S., Harber, M. J., Mackenzie, R. \& Asscher, A. W. (1981). Modified method for studying bacterial adhesion to isolated uroepithelial cells and uromucoid. Infection and Immunity 34, 256-261.

Cooke, E. M. \& Ewins, S. P. (1975). Properties of strains of Escherichia coli isolated from a variety of sources. Journal of Medical Microbiology 8, 107-111.

Cross, A. S., Gemski, P., Sadoff, J. C., Ørskov, F. \& Ørskov, I. (1984). The importance of the $\mathrm{K} 1$ capsule in invasive infections caused by Escherichia coli. Journal of Infectious Diseases 149, 184-193.

De Boy, J. M., W Achsmuth, J. K. \& Davis, B. R. (1980). Hemolytic activity in enterotoxigenic and non enterotoxigenic strains of Escherichia coli. Journal of Clinical Microbiology 12, 193-198.

Dudgeon, L. S., Wordley, E. \& Bawtree, F. (1921). On Bacillus coli infections of the urinary tract, especially in relation to haemolytic organisms. Journal of Hygiene A 20, 137-164.

Duguid, J. P. \& Gillies, R. R. (1957). Fimbriae and adhesive properties of dysentery bacilli. Journal of Pathology and Bacteriology 74, 397-411.

Duguid, J. P. \& OLD, D. C. (1980). Adhesive properties of Enterobacteriaceae. In Receptors and Recognition (ed. E. H. Beachy), series B, vol. 6, pp. 185-217. London: Chapman \& Hall.

Emödy, L., Pal, N., Safonova, N. V., Kuch, B. \& Golutva, N. K. (1980). Alpha-haemolysin: an additive virulence factor in Escherichia coli. Acta Microbiologica Academiae Scientiarum Hungaricae 27, 333-342.

Escherich, T. (1885a). Die Darmbakterien des Neugeborenen und Säuglings. Fortschritte der Medizin 3, 515-522.

Escherich, T. (1885b). Die Darmbakterien des Neugeborenen und Säuglings. Fortschritte der Medizin 3, 547-554.

Evans, D. J., Evans, D. G., Höhne, C., Noble, M. A., Haldane, E. V., Lior, H. \& Young, L. S. (1981). Hemolysin and $K$ antigens in relation to serotype and hemagglutination type of Escherichia coli isolated from extraintestinal infection. Journal of Clinical Microbiology 13, 171-178.

Ewhrtsen, H. W. (1946). Dyreexperimentelle Undersøgelser over Colibacillernes Patogenitet og Effekten af Coliserum, pp. 1-192. Copenhagen: Arnold Busck.

Fowler, J. E. JR \& Stamey, T. A. (1977). Studies of introital colonization in women with recurrent urinary infections. VII. The role of bacterial adherence. Journal of Urology 117, $472-476$.

GadeBeRg, O. V. \& ØRSKov, I. (1984). In vitro cytotoxic effect of $\alpha$-hemolytic Escherichia coli on human blood granulocytes. Infection and Immunity 45, 255-260. 
Gadeberg, O. V., Ørskov, I. \& Rhodes, J. M. (1983). Cytotoxic effect of an alpha-hemolytic Escherichia coli strain on human blood monocytes and granulocytes in vitro. Infection and Immunity 41, 358-364.

Gibson, F. \& Magrath, D. I. (1969). The isolation and characterization of a hydroxamic acid (aerobactin) formed by Aerobacter aerogenes 62-1. Biochemical and Biophysical Acta 192 , 175-184.

Glynn, A. A., Brumfitt, W. \& Howard, C. J. (1971). K antigens of Escherichia coli and renal involvment in urinary tract infections. Lancet i, 514-516.

Glynn, A. A. \& Howard, C. J. (1970). The sensitivity to complement of strains of Escherichia coli related to their $\mathrm{K}$ antigens. Immunology 18, 331-346.

Goldhar, J., Perry, R. \& OFek, I. (1984). Extraction and properties of nonfimbrial mannoseresistant hemagglutinin from a urinary isolate of Escherichia coli. Current Microbiology 11, 49-54.

Goldman, R. C., Joiner, K. \& Leive, L. (1984). Serum resistant mutants of Escherichia coli 0111 contain increased lipopolysaccharide, lack an $\mathrm{O}$ antigen containing capsule and have more of their lipid A core with $O$ antigen. Journal of Bacteriology 159, 877-882.

Gower, P. E., Taylor, P. W., Koutsaimanis, K. G. \& Roberts, A. P. (1972). Serum bactericidal activity in patients with upper and lower urinary tract infections. Clinical Science and Molecular Medicine 43, 13-22.

Grados, O. \& Ewing, W. H. (1970). Antigenic relationship between Escherichia coli and Neisseria meningitidis. Journal of Infectious Diseases 122, 100-103.

Gross, R. J., Cheasty, T. \& Rowe, B. (1977). Isolation of bacteriophages specific for the K 1 polysaccharide antigen of Escherichia coli. Journal of Clinical Microbiology 6, 548-550.

Grossman, N. \& LeIVe, L. (1984). Complement activation via the alternative pathway by purified Salmonella lipopolysaccharide is affected by its structure but not its $\mathrm{O}$ antigen length. Journal of Immunology 132, 376-385.

GRÜNEBERG, R. N. (1969). Relationship of infecting urinary organisms to the fecal flora in patients with symptomatic urinary infection. Lancet ii, 766-768.

GRÜNEBERG, R. N., Leigh, D. A. \& BRUMfitT, W. (1968). Escherichia coli serotypes in urinary infection: studies in domiciliary, antenatal and hospital practice. In Urinary Tract Infection (ed. F. O'Grady \& W. Brumfitt), pp. 68-79. London: Oxford University Press.

Hacker, J., Schröter, G., Schrettenbrunner, A., Hughes, C. \& Goebel, W. (1983). Hemolytic Escherichia coli strains in the hurnan fecal flora as potential urinary pathogens. Zentralblatt für Bakteriologie und Hygiene (I. Abt. Orig. A) 254, 370-378.

Hagberg, L., Engberg, I., Freter, R., Lam, J., Olling, S. \& Svanborg Edén, C. (1983a). Ascending, unobstructed urinary tract infection in mice caused by pyelonephritogenic Escherichia coli of human origin. Infection and Immunity 40, 273-283.

Hagberg, L., Hull, R., Hull, S., Falkow, S., Freter, R. \& Svanborg Edén, C. (1983b). Contribution of adhesin to bacterial persistence in the mouse urinary tract. Infection and Immunity 40, 265-272.

Hagberg, L., Hull, R., Hull, S., McGhee, J. R., Michalek, S. M. \& Svanborg Edén, C. (1984). Difference in susceptibility to gram-negative urinary tract infection between $\mathrm{C} 3 \mathrm{H} / \mathrm{HeJ}$ and $\mathrm{C} 3 \mathrm{H} / \mathrm{HeN}$ mice. Infection and Immunity 46, 839-844.

Hagberg, L., Jodal, U., Korhonen, T. K., Lidin-Janson, G., Lindberg, U. \& Svanborg EDÉn, C. (1981). Adhesion, haemagglutination, and virulence of Escherichia coli causing urinary tract infections. Infection and Immunity 31, 564-570.

Handrück, W., Steinrück, H., Spencker, F.-B., Braun, W. \& Vogtman, C. (1982). Infektionen durch E. coli in der Neonatalperiode. II. Bericht über 61 Erkrankungen. Deutsches Gesundheitswesen 37, 2212-2219.

Hanson, L. A., Ahlstedt, S., Fasth, A., Jodal, U., Kaijser, B., Larsson, P., Lindberg, U., Olling, S., Sohl-Åkerlund, A. \& Svanborg-Edén, C. (1977). Antigens of Escherichia coli, human immune response, and the pathogenesis of urinary tract infections. Journal of Infectious Diseases 136, Suppl. S144-149.

Harber, M. J., Chick, S., Mackenzie, R. \& Asscher, A. W. (1982). Lack of adherence to epithelial cells by freshly isolated urinary pathogens. Lancet i, 586-588.

Henkel, W. (1970). Serumresistenz und Nephropathogenität antigenetisch definierten Stämme von E. coli. Zeitschrift für Medizinische Mikrobiologie und Immunologie 156, 44-59.

Hughes, C., Phillips, R. \& Roberts, A. P. (1982). Serum resistance among Escherichia coli strains causing urinary tract infection in relation to $O$ type and the carriage of hemolysin, colicin, and antibiotic resistance determinants. Infection and Immunity 35, 270-275. 
Hull, R. A., Gill, R. E., Hsu, P., Minshew, B. H. \& Falkow, S. (1981). Construction and expression of recombinant plasmids encoding type 1, or D-mannose-resistant pili from a urinary tract infection Escherichia coli isolate. Infection and Immunity 33, 933-938.

$J_{A N N}, K . \& J_{A N N}$, B. (1983). The K antigens of Escherichia coli. Progress in Allergy 33, 53-79.

JANN, K., JANN, B. \& SchmidT, G. (1981). SDS polyacrylamide gel electrophoresis and serological analysis of pili from Escherichia coli of different pathogenic origin. FEMS Microbiology Letters 11, 21-25.

KAIJSER, B. (1973). Immunology of Escherichia coli: K antigen and its relation to urinary-tract infection. Journal of Infectious Diseases 127, 670-677.

KaiJser, B., Hanson, L. Å., Jodal, U., Lidin-Janson, G. \& Robbins, J. B. (1977). Frequency of $E$. coli $\mathrm{K}$ antigens in urinary-tract infections in children. Lancet i, 663-664.

Källenius, G. \& Möllby, R. (1979). Adhesion of Escherichia coli to human periurethral cells correlated to mannose-resistant agglutination of human erythrocytes. FEMS Microbiology Letters 5, 295-299.

Källenius, G., Möllby, R. \& Winberg, J. (1980). In vitro adhesion of uropathogenic Escherichia coli to human periurethral cells. Infection and Immunity 28, 972-980, 1980.

Källenius, G., Möllby, R., Svenson, S. B., Winberg, J. \& Hultbera, H. (1980). Identification of a carbohydrate receptor recognized by uropathogenic Escherichia coli. Infection, Suppl. 3, S288-293.

Källenius, G., Svenson, S. B., Hultberg, H., Möllby, R., Helin, I., Cedergren, B. \& WinBerg, J. (1981). Occurrence of P-fimbriated Escherichia coli in urinary tract infections. Lancet ii, 1369-1372.

Kauffmann, F. (1940). Zur Serologie des I-Antigens in der Salmonella Gruppe. Acta Pathologica et Microbiologica Scandinavica 17, 135-144.

KaUfrmann, F. (1943). Über neue thermolabile Körperantigene der Coli-Bakterien. Acta Pathologica et Microbiologica Scandinavica 20, 21-44.

Kauffmann, F. (1944a). Zur Serologie der Coli-Gruppe. Acta Pathologica et Microbiologica Scandinavica 21, 20-45.

KaUffmann, F. (1944b). Untersuchungen über die Körper-Antigene der Coli-Bakterien. Acta Pathologica et Microbiologica Scandinavica 21, 46-64.

Kauffmann, F. (1947). The serology of the Coli group. Journal of Immunology 57, 71-100.

Kauffmann, F. \& Vahlne, G. (1945). Über die Bedeutung des serologischen Formenwechsels für de Bakteriophagenwirkung in der Coli-Gruppe. Acta Pathologica et Microbiologica Scandinavica 22, 119-137.

KÉTYI, I. (1981). Suckling mouse model of urinary tract infections caused by Escherichia coli. Acta Microbiologica Academiae Scientiarum Hungaricae 28, 393-399.

Kétyi, I., Emödy, L., Kontrohr, T., Vertenyi, A., Pacsa, S., Avdeeva, T. A., Safonova, N. V. \& Golutova, N. K. (1978). Mouse lung oedema caused by a toxic substance of Escherichia coli strains. Acta Microbiologica Academiae Scientiarum Hungaricae 25, 307-317.

Kе́tyi, I., Naumann, G. \& Nimmich, W. (1983). Urinary tract infectivity of $\mathrm{R}$ strains of Escherichia coli carrying various virulence factors. Acta Microbiologica Academiae Scientiarum Hungaricae 30, 155-161.

KLemM, P., ØRSkov, I., \& Ørskov, F. (1983). Isolation and characterization of F12 adhesive fimbrial antigen from uropathogenic Escherichia coli strains. Infection and Immunity 40, 91-96.

Knipschildt, H. E. (1945). Undersøgelser over Coligruppens Serologi, pp. 1-156. Copenhagen: Nyt Nordisk Forlag, Arnold Busck.

Korhonen, T. K., Leffler, H. \& Svanborg Edén, C. (1981). Binding specificity of piliated strains of Escherichia coli and Salmonella typhimurium to epithelial cells, Saccharomyces cerevisiae and erythrocytes. Infection and Immunity 32, 796-804.

Korhonen, T. K., Väisänen, V., Saxén, H., Hultberg, H. \& Svenson, S. B. (1982). P-antigen-recognizing fimbriae from human uropathogenic Escherichia coli strains. Infection and Immunity 37, 286-291.

Korhonen, T. K., Väisänen-Rhen, V., Rhen, M., Pere, A., Parkinen, J. \& Finne, J. (1984). Escherichia coli fimbriae recognizing sialyl galactosides. Journal of Bacteriology 159, 762-766, 1984.

Korhonen, T. K., Valtonen, M. V., Parkinen, J., Väisänen-Rhen, V., Finne, J., Ørskov, F., Ørskov, I., Svenson, S. B. \& Mäk elä, P. H. (1985) Escherichia coli strains associated with neonatal sepsis and meningitis: Serotypes, hemolysin production and receptor recognition. Infection and Immunity 48, 486-491. 
Kreger, B. E., Craven, D. E., Carling, P. C. \& McCabe, W. R. (1980). Gram-negative bacteremia. III. Reassessment of etiology, epidemiology and ecology in 612 patients. American Journal of Medicine 68, 332-343.

Kunin, C. M. (1982). Urinary tract infection: new information concerning pathogenesis and management. Journal of Urology 128, 1233.

Kunin, C. M., Deutscher, R. \& Paquin, A. (1964). Urinary tract infection in school children: an epidemiological, clinical and laboratory study. Medicine 43, 91-130.

Labigne-Roussel, A. F., Lark, D., Schoolnik, G. \& Falkow, S. (1984). Cloning and expression of an afimbrial adhesin (AFA-I) responsible for P blood group-independent, mannose-resistant hemagglutination from a pyelonephritic Escherichia coli strain. Infection and Immunity 46, 251-259.

Leffler, H. \& Svanborg Edén, C. (1981). Chemical identification of a glycosphincolipid receptor for Escherichia coli attaching to human urinary epithelial cells and agglutinating human erythrocytes. FEMS Microbiology Letters 8, 127-134.

Lidin-Janson, G., Hanson, L. Å., Kaijser, B., Lincoln, K., Lindberg, U., Olling, S. \& WEDEL, H. (1977). Comparison of Escherichia coli from bacteriuric patients with those from faeces of healthy school children. Journal of Infectious Diseases 136, 346-353.

Lindberg, U., Hanson, L. Å., Jodal, U., Lidin-JAnson, G., Lincoln, K. \& Olling, S. (1975a). Asymptomatic bacteriuria in schoolgirls. II. Differences in Escherichia coli causing asymptomatic and symptomatic bacteriuria. Acta Paediatrica Scandinavica 64, 432-436.

Lindberg, U., Jodal, U., Hanson, L. Å. \& KaIJSer, B. (1975b). Asymptomatic bacteriuria in schoolgirls. IV. Difficulties of level diagnosis and the possible relation to the character of infecting bacteria. Acta Paediatrica Scandinavica 64, 574-580.

LingGood, M. A. \& Ingram, P. L. (1982). The role of alpha haemolysin in the virulence of Escherichia coli for mice. Journal of Medical Microbiology 15, 23-30.

Lomberg, H., Hellström, M., Jodal, U., Leffler, H., Lincoln, K. \& Svanborg Edén, C. (1984). Virulence-associated traits in Escherichia coli causing first and recurrent episodes of urinary tract infection in children with or without reflux. Journal of Infectious Diseases 150, $561-569$.

Mabeck, C. E., ØRskov, F. \& ØRskov, I. (1971 a). Escherichia coli serotypes and renal involvement in urinary tract infection. Lancet i, 1312-1314.

MaвеCK, C. E., ØRSkov, F. \& ØRSkov, I. (1971b). Studies in urinary tract infections. VIII. Escherichia coli O: H serotypes in recurrent infections. Acta Medica Scandinavica 190, 279-282.

McCabe, W. R., Carling, P. C., Bruins, S. \& Greely, A. (1975). The relation of K antigen to virulence of Escherichia coli. Journal of Infectious Diseases 131, 6-10.

McCabe, W. R., KaiJser, B., Ollings, J., Uwaydah, M. \& Hanson, L. Ȧ. (1978). Escherichia coli in bacteremia: $\mathrm{K}$ and $\mathrm{O}$ antigens and serum sensitivity of strains from adults and neonates. Journal of Infectious Diseases 138, 33-41.

McCracken, G. H., Sarff, L. D., Glode, M. P., Mize, S. G., Schiffer, M. S., Robbins, J. B., Gotschlich, E. C. ØRSkov, I. \& Ørskov, F. (1974). Relation between Escherichia coli K 1 capsular polysaccharide antigen and clinical outcome in neonatal meningitis. Lancet ii, 246-250.

McGeachie, J. (1965). Serological grouping of urinary Escherichia coli. Journal of Clinical Pathology 18, 428-431.

Maiztegui, J. I., Biegeleisen, J. Z. JR, Cherry, W. B. \& KaAs, E. H. (1965). Bacteriemia due to gram-negative rods. A clinical bacteriologic, serologic, and immunofluorescent study. New England Journal of Medicine 272, 222-229.

Mangan, D. F. \& SNYDer, I. S. (1979). Mannose-sensitive interaction of Escherichia coli with human peripheral leucocytes in vitro. Infection and Immunity 26, 520-527.

Minshew, B., Jorgensen, J., Counts, G. W. \& Falkow, S. (1978). Association of hemolysin production, hemagglutination of human erythrocytes, and virulence for chicken embryos of extraintestinal Escherichia coli isolates. Infection and Immunity 20, 50-54.

Moll, A., Manning, P. A. \& Timmis, K. N. (1980). Plasmid-determined resistance to serum activity : a major membrane protein, the tra $T$ gene product is responsible for plasmid specified serum resistance in Escherichia coli. Infection and Immunity 28, 359-367.

Mulder, C. J. J., van Alphen, L. \& Zanen, H. C. (1984). Neonatal meningitis caused by Escherichia coli in The Netherlands. Journal of Infectious Diseases 150, 935-940.

Mulder, C. J. J. \& Zanen, H. C. (1984). A study of 280 cases of neonatal meningitis in The Netherlands. Journal of Infection 8, 177-184. 
Myerowitz, R. L., Albers, A. C., Yee, R. B. \& Ørskov, F. (1977). Relationship of K 1 antigen to biotype in clinical isolates of Escherichia coli. Journal of Clinical Microbiology 6, 124-127.

Nowicki, B., Rhen, M., Väisänen-Rhen, V., Pere, A. \& Korhonen, T. K. (1984). Immunofluorescence study of fimbrial phase variation in Escherichia coli KS71. Journal of Bacteriology 160, 691-695.

O'Hanley, P., Lark, D., Falkow, S. \& Schoolnik, G. (1985). Molecular basis of Escherichia coli colonization of the upper urinary tract in BALB/c mice: gal-gal pili immunization prevents $E$. coli pyelonephritis. Journal of Clinical Investigation 75, 347-360.

Olling, S. (1977). Sensitivity of gram-negative bacilli to the serum bactericidal activity: A marker of host-parasite relationship in acute and persisting infections. Scandinavian Journal of Infectious Diseases, Suppl. 10, 1-40.

Olling, S., Hanson, L. A., Holmgren, J., Jodal, U., Lincoln, K. \& Lindberg, U. (1973). The bactericidal effect of normal human serum on $E$. coli strains from normals and from patients with urinary tract infections. Infection 1, 24-28.

Opal, S., Cross, A. \& Gemski, P. (1982). K antigen and serum sensitivity of rough Escherichia coli. Infection and Immunity 37, 956-960.

Ørskov, I., Birch-Andersen, A., Duguid, J., Stenderup, J. \& Ørskov, F. (1985). An adhesive protein capsule of Escherichia coli. Infection and Immunity 47, 191-200.

Ørskov, I., Ferencz, A., \& Ørskov, F. (1980). Tamm-Horsfall protein or uromucoid is the normal urinary slime that traps type 1 fimbriated Escherichia coli. Lancet i, 887.

ØRSKov, F. \& ØRSKOv, I. (1967). In: Round table conference on non-obstructive urinary tract infections in children. Proceedings of the 15th Northern Pediatric Congress, Bergen, 1967. Acta Paediatrica Scandinavica, suppl. 177, 44-45.

ØRSkov, F. \& ØRSkov, I. (1975). Escherichia coli O:H serotypes isolated from human blood. Acta Pathologica et Microbiologica Scandinavica B 83, 585-600.

Ørskov, I. \& Ørskov, F. (1983). Serology of Escherichia coli fimbriae. Progress in Allergy 33, 80-105.

Ørskov, I. \& ØRSkov, F. (1985). Some Escherichia coli adhesins. In Seminars in Infectious Diseases. Vol. V. Bacterial Vaccines. (In the Press.)

Ørskov, I., Ørskov, F. \& Birch-ANDERSEn, A. (1980). Comparison of Escherichia coli fimbrial antigen $\mathrm{F} 7$ with type 1 fimbriae. Infection and Immunity 27, 657-666.

Ørskov, I., Ørskov, F., Birch-Andersen, A., Kanamori, M. \& Svanborg Edén, C. (1982b). $\mathrm{O}, \mathrm{K}, \mathrm{H}$ and fimbrial antigens in Escherichia coli serotypes associated with pyelonephritis and cystitis. Scandinavian Journal of Infectious Diseases, suppl. 33, 18-25.

Ørskov, I., Ørskov, F., Birch-Andersen, A., Klemm, P. \& Svanborg Edén, C. (1982a). Protein attachment factors: fimbriae in adhering Escherichia coli. In Seminars in Infectious Diseases. Vol. IV. Bacterial Vaccines, pp. 97-103. New York: Thieme-Stratton.

Ørskov, F., Ørskov, I., Evans, D. J., SaCk, R. B., SACk, P. A.\& WADSTröm, T. (1976). Special Escherichia coli serotypes among enterotoxigenic strains from diarrhoea in adults and children. Medical Microbiology and Immunology 162, 73-80.

ØRSkov, F., ØRSkov, I., JANN, B. \& JANN, K. (1971). Immunoelectrophoretic patterns of extracts from all Escherichia coli $\mathrm{O}$ and $\mathrm{K}$ antigen test strains. Correlation with pathogenicity. Acta Pathologica et Microbiologica Scandinavica, B, 79, 142-152.

ØrSkov, I., ØRSkov, F., JANN, B. \& JANN, K. (1977). Serology, chemistry, and genetics of $\mathrm{O}$ and $\mathrm{K}$ antigens of Escherichia coli. Bacteriological Reviews 41, 667-710.

Ørskov, F., Ørskov, I., Sutron, A., Schneerson, R., Lin, W., Egen, W., Hoff, G. E. \& Roвbins, J. B. (1979). Form variation in Escherichia coli K 1 : Determined by O-acetylation of the capsular polysaccharide. Journal of Experimental Medicine 149, 669-685.

Parkinen, J., Finne, J., Achtman, M., Väisänen, V. \& Korhonen, T. K. (1983). Escherichia coli strains binding neuraminyl $\alpha 2-3$ galactosides. Biochemical and Biophysical Research Communications 111, 456-461.

Pluschke, G. \& Achtman, M. (1984). Degree of antibody-independent activation of the classical complement pathway by $\mathrm{K} 1$ Escherichia coli differs with $\mathrm{O}$ antigen type and correlates with virulence of meningitis in newborns. Infection and Immunity 43, 684-692.

Pluschke, G., Mayden, J., Achtman, M. \& Levine, R. P. (1983). Role of capsule and the $\mathrm{O}$ antigen in resistance of $\mathrm{O} 18: \mathrm{K} 1$ Escherichia coli to complement-mediated killing. Infection and Immunity 42, 907-913.

Quackenbush, R. L. \& Falkow, S. (1979). Relationship between Colicin V activity and virulence in Escherichia coli. Infection and Immunity 24, 562-564. 
Rantz, L. A. (1962). Serological grouping of Escherichia coli. Archives of Internal Medicine 109. $37-42$.

Rhen, M., Mäkelä, P. H. \& Korhonen, T. K. (1983). P-fimbriae of Escherichia coli are subject to phase variation. FEMS Microbiology Letters 19, 267-271.

Robbins, J. B., Mc Cracken, G. H., Gotschlich, E. C., Ørskov, F., Ørskov, I. \& Hanson, L. A. (1974a). Escherichia coli $\mathrm{K} 1$ capsular polysaccharide associated with neonatal meningitis. New England Journal of Medicine 290, 1216-1220.

Robrins, J. B., Parke, J. C., Jr, Schneerson, R. \& Whisnant, J. K. (1973). Quantitative measurement of 'natural' and immunization-induced Haemophilus influenzae type b capsular polysaccharide antibodies. Pediatric Research 7, 103-110.

Robbins, J. B., Schneerson, R., Liu, T. Y., Schiffer, M. S., Schiffman, G., Myerowitz, R. L., McCracken, G. H., Ørskov, I. \& Ørskov, F. (1974b). Cross-reacting bacterial antigens and immunity to disease caused by encapsulated bacteria. 4th International Convocation on Immunology, Buffalo, N.Y., 1974 (ed. E. Neter and F. Milgrom), pp. 218-241. Basel: S. Karger.

Robbins, J. B., Schneerson, R., Parke, J. C., Liu, T. Y., Handzel, Z. T., Ørskov, I. \& ØRSKov, F. (1976). Escherichia coli $\mathrm{O} 75: \mathrm{Kf} 147: \mathrm{H} 5$ cross reactive with capsular polysaccharide of Haemophilus influenzae type B: studies of the immunochemical relationship and properties of heteroimmunization in humans to prevent septicemic disease caused by $H$. influenzae type B. In The Role of Immunological Factors in Infections, Allergy and Autoimmune Processes (ed. R. F. Beers Jr and E. G. Bassett), pp. 103-120. New York: Raven Press.

Rowley, D. (1968). Sensitivity of rough gram-negative bacteria to the bactericidal action of serum. Journal of Bacteriology 95, 1647-1650.

Sack, R. \& Miller, C. E. (1969). Progressive changes of Vibrio serotypes in germ-free mice infected with Vibrio cholerae. Journal of Bacteriology 99, 688-695.

Salit, I. E. \& Gotschlich, E. C. (1977). Type 1 Escherichia coli pili :characterization of binding, to monkey kidney cells. Journal of Experimental Medicine 146: 1182-1194.

Sarff, L. D., McCracken, G. H., Schiffer, M. S., Glode, M. P., Robbins, J. B., Ørskov, I. \& ØRSKov, F. (1975). Epidemiology of Escherichia coli K 1 in healthy and diseased newborns. Lancet i, 1099-1104.

Schafffer, A. J., Amundsen, S. K. \& Schmidt, L. N. (1979). Adherence of Escherichia coli to human urinary tract epithelial cells. Infection and Immunity 24: 753-759.

Schafffer, A. J., Jones, J. M., Duncan, J. L., Chmiel, J. S., Plotkin, B. J. \& Falkowski, W. S. (1982). Adhesion of uropathogenic Escherichia coli to epithelial cells from women with recurrent urinary tract infection. Infection 10, 186-191.

Schneerson, R., Bradshaw, M., Whinant, J. K., Myerowitz, R. L., Parke, J. C., JR \& Roвbins, J. B. (1972). An Escherichia coli antigen cross-reactive with capsular polysaccharide of Haemophilus influenzae type b. Journal of Immunology 108, 1551-1562.

Sietzen, W. (1979). Typisierung von Escherichia-coli-O- und -K-Antigenen bei Patienten mit Harnwegsinfektionen. Infektion 7, Suppl. 2, S 197-S206.

Silver, R. P., Finn, C. W., Vann, W. F., Aronson, W., Schneerson, R., Kretschmer, P. J. \& GaRon, C. F. (1981). Molecular cloning of the K 1 capsular polysaccharide genes of E. coli. Nature (London) 289, 696-698.

Silver, R. P., Vann, W. F. \& Aronson, W. (1984). Genetic and molecular analysis of Escherichia coli $\mathrm{K} 1$ antigen genes. Journal of Bacteriology 157, 568-575.

Silverblatt, F. J., Dreyer, J. S. \& Schauer, S. (1979). Effect of pili on susceptibility of Escherichia coli to phagocytosis. Infection and Immunity 24, 218-223.

SJöstedt, S. (1946). Pathogenicity of certain serological types of $E$. coli. Their mouse toxicity, hemolytic power, capacity for skin necrosis and resistance to phagocytosis and bactericidal faculties of human blood. Acta Pathologica et Microbiologica Scandinavica, Suppl. 63, 1-148.

Sмiтн, H. W. (1963). The haemolysins of Escherichia coli. Journal of Pathology and Bacteriology 83, 197-211.

Smith, H. W. \& Huggins, M. B. (1980). The association of O18, K 1 and H 7 antigens and the Col V plasmid of a strain of Escherichia coli with its virulence and immunogenicity. Journal of General Microbiology 121, 387-400.

Smith, H. W. \& Huggins, M. B. (1985). The toxic role of alphahaemolysin in the pathogenesis of experimental Escherichia coli infection in mice. Journal of General Microbiology 131, 395-403.

Sмiтh, H. W. \& LingGood, M. A. (1971). Observations on the pathogenic properties of the K 88, Hly and Ent plasmids of Escherichia coli with particular reference to porcine diarrhoea. Journal of Medical Microbiology 4, 467-485. 
Sмітн, T. (1927). Studies on pathogenic B. coli from bovine sources. III. Normal and serological induced resistance to B. coli and its mutant. Journal of Experimental Medicine 46, 141-153.

Stamm, W. E., Counts, G. W., Running, K. R., Film, S., Turck, M. \& Holmes, K. K. (1982). Diagnosis of coliform infection in acutely dysuric women. New England Journal of Medicine 307, 463-468.

Stevens, P., Chu, C. L. \& Young, L. S. (1980). K 1 antigen content and the presence of an additional sialic acid containing antigen among bacteriemic K1 Escherichia coli: correlation with susceptibility to opsonophagocytosis. Infection and Immunity 29, 1055-1061.

Stevens, P., Huang, N.-Y., Wells, W. D. \& Young, L. S. (1978). Restricted complement activation by Escherichia coli with K 1 capsular serotype: a possible role in pathogenicity. Journal of Immunology 121, 2174-2180.

Svanborg Edén, C., Buursten, L. M., Hull, R., Hull, S., Magnusson K.-E., Moldovano, Z. \& LEFFLER, H. (1984). Influence of adhesins on the interaction of Escherichia coli with human phagocytes. Infection and Immunity 44, 672-680.

Svanborg Edén, C., Eriksson, B., Hanson, L. Å., Jodal, U., Kaijser, B., Lidin Janson, G., LindBerg, U. \& Olling, S. (1978). Adhesion to normal human uroepithelial cells of Escherichia coli from children with various forms of urinary tract infection. Journal of Pediatrics 93, 398-403.

Svanborg Edén, C., Gotschlich, E. C., Korhonen, T. K., Leffler, H. \& Schoolnik, G. $(1983 a)$. Aspects on structure and function of pili on uropathogenic Escherichia coli. Progress in Allergy 33, 189-202.

Svanborg Edén, C., Hagberg, L., Hanson, L. Å., Lomberg, H., Ørskov, I., \& Ørskov, F. (1982). Bacterial adherence and urinary tract infection. Lancet i, 961-962.

Svanborg Edén, C., Hagberg, L., Hanson, L. Å., Hull, S., Hull, R., Jodal, U., Leffler, H., Lomberg, H. \& Straube, E. (1983b). Bacterial adherence, a pathogenic mechanism in urinary tract infection caused by Escherichia coli. Progress in Allergy 33, 175-188.

Svanborg Edén, C. \& Hansson, H. A. (1978). Escherichia coli pili as possible mediators of attachment to human urinary tract epithelial cells. Infection and Immunity 21, 229-237.

Svanborg Edén, C., Hanson, L. Å., Jodal, U., Lindberg, U. \& Åkerlund, A. S. (1976). Variable adherence to normal human urinary-tract epithelial cells of Escherichia coli strains associated with various forms of urinary-tract infection. Lancet ii, 490-492.

Svanborg Edén, C., Jodal, U., Kaijser, B., Leffler, H., Lomberg, H., Ørskov, F. \& Ørskov, I. (1985). Adhesive properties and O, K, H and F antigens of $E$. coli associated with recurrent pyelonephritis. In Seminars in Infections Diseases. Vol. V. Bacterial Vaccines. (In the Press.)

TAYLOR, P. W. (1974). Sensitivity of some smooth strains of $E$. coli to the bactericidal action of normal human serum. Journal of Clinical Pathology 27, 626-629.

TAYLOR, P. W. (1975). Genetical studies of serum resistance in Escherichia coli. Journal of General Microbiology 89, 57-66.

TAYLOR, P. W. (1976). Immunochemical investigations of lipopolysaccharides and acidic polysaccharides from serum-sensitive and serum-resistant strains of Escherichia coli from urinary tract infections. Journal of Medical Microbiology 9, 405-412.

TAYLOR, P. W. (1983). Bactericidal and bacteriolytic activity of serum against gram-negative bacteria. Microbiological Reviews 47, 46-83.

TAYLOR, P. W. \& PARTON, R. (1976). A protein associated with serum resistance in Escherichia coli. Journal of Medical Microbiology 10, 225-232.

TAYlOR, P. W. \& Robinson, M. K. (1980). Determinants that increase the serum resistance of Escherichia coli. Infection and Immunity 29, 278-280.

Timmis, K. N., Manning, P. A., Echarti, C., Timmis, J. K. \& Moll, A. (1981). Serum resistance in E. coli. In Molecular Biology, Pathogenicity and Ecology of Bacterial Plasmids (ed. S. B. Levy, R. C. Clowes and E. L. Koenig), pp. 133-144. New York: Plenum.

Tullus, K., Hörlin, K., Svenson, S. B. \& Källenius, G. (1984). Epidemic outbreaks of acute pyelonephritis caused by nosocomal spread of $\mathrm{P}$ fimbriated Escherichia coli in children. Journal of Infectious Diseases 150, 728-736.

Turck, M., Petersdorf, R. G. \& Fournier, M. R. (1962). The epidemiology of non-enteric Escherichia coli infections: prevalence of serologic groups. Journal of Clinical Investigation 41, 1760-1765.

Uhlenhuth, P. (1897). Beiträge zur Pathogenität des Bacterium coli. Zeitschrift für Hygiene und Infektionskrankheiten 26, 476-484. 
VAhi,ne, G. (1945). Serological typing of the colon bacteria. Acta Pathologica et Microbiologica Scandinavica 62 (Suppl.), 1-127.

Valvano, M. A. \& Crosa, J. H. (1984). Aerobactin iron transport genes commonly encoded by certain Col V plasmids occur in the chromosome of a human invasive strain of Escherichia coli $\mathrm{K} 1$. Infection and Immunity 46, 159-167.

van den Bosch, J. F., De Graaf, J. \& MacLaren, D. M. (1979). Virulence of Escherichia coli in experimental hematogenous pyelonephritis in mice. Infection and Immunity 25, 68-74.

van den Bosch, J. F., EMödy, L., \& KÉTYI, I. (1982). Virulence of haemolytic strains of Escherichia coli in various animal models. FEMS Microbiology Letters 13, 427-430.

van den Bosch, J. F., Postma, P., de Graaf, J. \& MacLaren, D. M. (1981). Haemolysis by urinary Escherichia coli and virulence in mice. Journal of Medical Microbiology 14, 321-331.

van Dijk, W. C., Verbrugh, H. A., Peters, R., van der Tol, M. E., Peterson, P. K. \& VERHOEF, J. (1979). Escherichia coli $\mathrm{K}$ antigen in relation to serum induced lysis and phagocytosis. Journal of Medical Microbiology 12, 123-130.

VARIAN, S. A. \& Cooke, E. M. (1980). Adhesive properties of Escherichia coli from urinary-tract infections. Journal of Medical Microbiology 13, 111-119.

VeriveiJ-van Vught, A. M. J. J., van den Bosch, J. F., Namavar, F., Sparrius, M. \& MacLaren, D. M. (1983). K antigens of Escherichia coli and virulence in urinary-tract infection. Studies in a mouse model. Medical Microbiology 16, 147-155.

Vosti, K. G., Goldberg, L. M., Monto, A. S. \& Rantz, L. A. (1964). Host parasite interaction in patients with infections due to $E$. coli. I. The serogrouping of $E$. coli from intestinal and extraintestinal sources. Journal of Clinical Investigation 43, 2377-2385.

VÄISÄNEN-RHEN, V. (1984). Fimbria-like hemagglutinin of Escherichia coli 075 strains. Infection and Immunity 46, 401-407.

Väisänen-Rhen, V., Elo, J., Väisänen, E., Siitonen, A., Ørskov, I., Ørskov, F., Svenson, S. B., Mäk ElÄ, P. H. \& Korhonen, T. K. (1984). P-fimbriated clones among uropathogenic Eschericia coli strains. Infection and Immunity 43, 149-155.

Väisänen, V., Korhonen, T. K., Jokinen, M., Gahmberg, C. G. \& Ehnholm, C. (1982). Blood group M specific haemagglutinin in pyelonephritogenic Escherichia coli. Lancet i, 1192.

WAALWIJK, C. \& DE GRAAF, J. (1983). Inactivation of haemolysin production in Escherichia coli by transposon insertion results in loss of virulence. Antonie van Leeuwenhoek; Journal of Microbiology and Serology 49, 23-30.

WaalwiJk, C., Maclaren, D. M. \& de Graaf, J. (1983). In vivo function of hemolysin in the nephropathogenicity of Escherichia coli. Infection and Immunity 42, 245-249.

Waalwijk, C., van den Bosch, J. F., Macharen, D. M. \& de Graaf, J. (1982). Hemolysin plasmid coding for the virulence of a nephropathogenic Escherichia coli strain. Infection and Immunity 35, 32-37.

Warner, P. J., Williams, P. H., Bindereif, A. \& Neiland, J. B. (1981). Col V plasmid-specified aerobactin synthesis by invasive strains of Escherichia coli. Infection and Immunity. 33, $540-545$.

Webb, L., Goodwin, C. S. \& Green, J. (1982). O antigen loss by semirough E. coli causing recurrent urinary infections, analysed by gel column filtration and gas-liquid chromatography. Pathology 14, 17-24.

Weinstein, R. J. \& Young, L. S. (1976). Neutrophil function in gram-negative rod bacteremia: the interaction between phagocytic cells, infecting organisms and humoral factors. Journal of Clinical Investigation 58, 190-199.

Weinstein, R. \& Young, L. S. (1978). Phagocytic resistance of E. coli K1 isolates and relationship to virulence. Journal of Clinical Microbiology 8, 748-755.

Welch, R. A., Dellinger, E. P., Minshew, B. \& Falkow, S. (1981). Haemolysin contributes to virulence of extra-intestinal $E$. coli infections. Nature (London) 293, 665-667.

Williams, P. H. (1979). Novel iron uptake system specified by Col V plasmids: an important component in the virulence of invasive strains of Escherichia coli. Infection and Immunity 26, 925-932. 